Article

\title{
Empirical Operational Energy Analysis of Downtown High-Rise vs. Suburban Low-Rise Lifestyles: A Chicago Case Study
}

\author{
Peng Du ${ }^{1, *}$, Antony Wood ${ }^{1}$ and Brent Stephens ${ }^{2}$ \\ 1 College of Architecture, Illinois Institute of Technology/Council on Tall Buildings and Urban Habitat, \\ 3360 South State Street, Chicago, IL 60616, USA; awood@ctbuh.org \\ 2 Department of Civil, Architectural and Environmental Engineering, Illinois Institute of Technology, \\ 3201 South Dearborn Street, Chicago, IL 60616, USA; brent@iit.edu \\ * Correspondence: pdu@iit.edu; Tel.: +1-312-806-9757
}

Academic Editor: Jukka Heinonen

Received: 12 April 2016; Accepted: 24 May 2016; Published: 9 June 2016

\begin{abstract}
It is widely accepted that the concentration of people living in high-density city centers offers greater operational energy efficiency and lower greenhouse gas emissions than lower-density expanded suburbs. The prevailing assumption is that lower-density suburbs are dominated by larger low-rise buildings that have higher building energy use requirements and greater per-person automobile travel requirements than high-density city centers dominated by medium- and high-rise buildings located in close proximity to a variety of public transit systems. However, very few studies to date have utilized empirical data at an individual household scale to evaluate differences in the operational energy (OE) footprints for both building and transportation energy end-uses between high-rise urban and low-rise suburban households. Therefore, this work collects empirical data on building and transportation OE consumption by individuals and households living in two economically similar groups: existing high-rise residential buildings in downtown Chicago, IL, USA and existing low-rise residential buildings in suburban Oak Park, IL, USA. Data were collected from over 500 households via an online survey. We considered the following components of residential living: (1) building $\mathrm{OE}$ (BOE), which includes electricity and/or natural gas use for all building energy end-uses; and (2) transportation OE (TOE), which includes the OE for multiple modes of transportation (i.e., automobile, bus, subway, regional train, etc.) based on average travel behavior in each location, as well as the $\mathrm{OE}$ for supporting transportation infrastructure. We estimate that downtown high-rise living in this sample of residences in Chicago, IL accounts for approximately 427 GJ of primary OE per household per year, on average, which was $14 \%$ lower than the average for suburban low-rise living in the Oak Park, IL homes (499 GJ per household per year). However, on a per-person basis, downtown high-rise living accounts for approximately $246 \mathrm{GJ}$ of primary OE per person per year, which was approximately $61 \%$ higher than suburban low-rise living (153 GJ per person per year). In both building types, building $\mathrm{OE}$ was the single largest contributor to total OE use. This study accurately captured the energy requirements associated with realistic behaviors and lifestyles of occupants of both low-rise suburban and high-rise urban households, and found that building OE dominates the total OE, which suggests that efforts to reduce building OE should be given high priority in building design and management as well as urban planning.
\end{abstract}

Keywords: operational energy; high-rise; low-rise; life style; transportation; infrastructure; Chicago

\section{Introduction}

The United Nations forecasts that $70 \%$ of the world's projected 9 billion inhabitants will live in urban areas by the year 2050, up from 51\% of 7 billion urbanized inhabitants as of 2010 [1]. The enormity 
of this total figure of 2.8 billion people moving into cities over the next 40 years is perhaps more clearly appreciated when converted into an annual rate of 70 million people per year, or nearly 200,000 people per day. The human race will need to build a new or expanded city of more than one million people every week for the next 40 years to cope with this urban growth.

It is widely accepted that the concentration of people in high-density city centers, which are dominated by medium- and high-rise buildings located close to a variety of public transit systems, offers greater energy efficiency and lower greenhouse gas (GHG) emissions than lower-density expanded suburbs, which are dominated by larger low-rise buildings with higher building energy use requirements and greater per-person automobile travel requirements [2-6]. However, a number of recent studies have challenged this notion by attempting to quantify the operational energy (OE) use (and sometimes also the embodied energy [EE] use) of buildings, transportation, and supporting infrastructure. Findings have been mixed: while several recent studies conclude that high-density urban areas are indeed more energy- or carbon-efficient on a life cycle basis [3,7-10], other recent studies suggest otherwise [11-17]. However, very few studies to date have utilized empirical data at an individual household scale to evaluate differences in the OE footprints for both building and transportation energy end-uses between high-rise urban and low-rise suburban households and occupants. Further, very little data is available in the literature on the OE use of high-rise buildings, which limits direct comparisons between high-rise and low-rise buildings [18].

Therefore, this work collects empirical data on OE consumption by individuals and households living in existing high-rise residential buildings in downtown Chicago, IL, USA and in existing low-rise residential buildings in suburban Oak Park, IL, USA. We consider the following components of residential living: (1) building $\mathrm{OE}$ (BOE), which includes electricity and/or natural gas use for all building energy end-uses; and (2) transportation OE (TOE), which includes the OE for multiple modes of transportation (i.e., automobile, bus, subway, regional train, etc.) based on average travel behavior in each location, as well as the OE for supporting transportation infrastructure. This study focuses on OE for two main reasons. First, several studies have shown that OE for both building and transportation end-uses typically dominates the total life-cycle energy consumption compared to the EE requirements for the acquisition of raw materials, their processing, manufacturing, transportation to site, construction, maintenance, and replacement of materials or systems $[3,7,12]$. Second, most previous studies have used population-average assumptions for travel patterns and building energy use; however, more empirical data are needed to accurately capture the energy requirements associated with realistic behaviors and lifestyles of occupants of both low-rise suburban and high-rise urban households.

\section{Case Studies and Methodology}

Households in four existing residential towers spanning two downtown Chicago, IL locations (Chicago Loop and Lakeview) were recruited as the downtown high-rise case studies. The low-rise case study homes included existing single-family detached homes and several duplex/townhomes recruited in suburban Oak Park, IL, USA. Their geographic locations and connected transportation systems are shown in Figure 1. These areas were chosen for convenience, but also reflect two distinct urban and suburban residential areas in a major metropolitan area in the United States. 


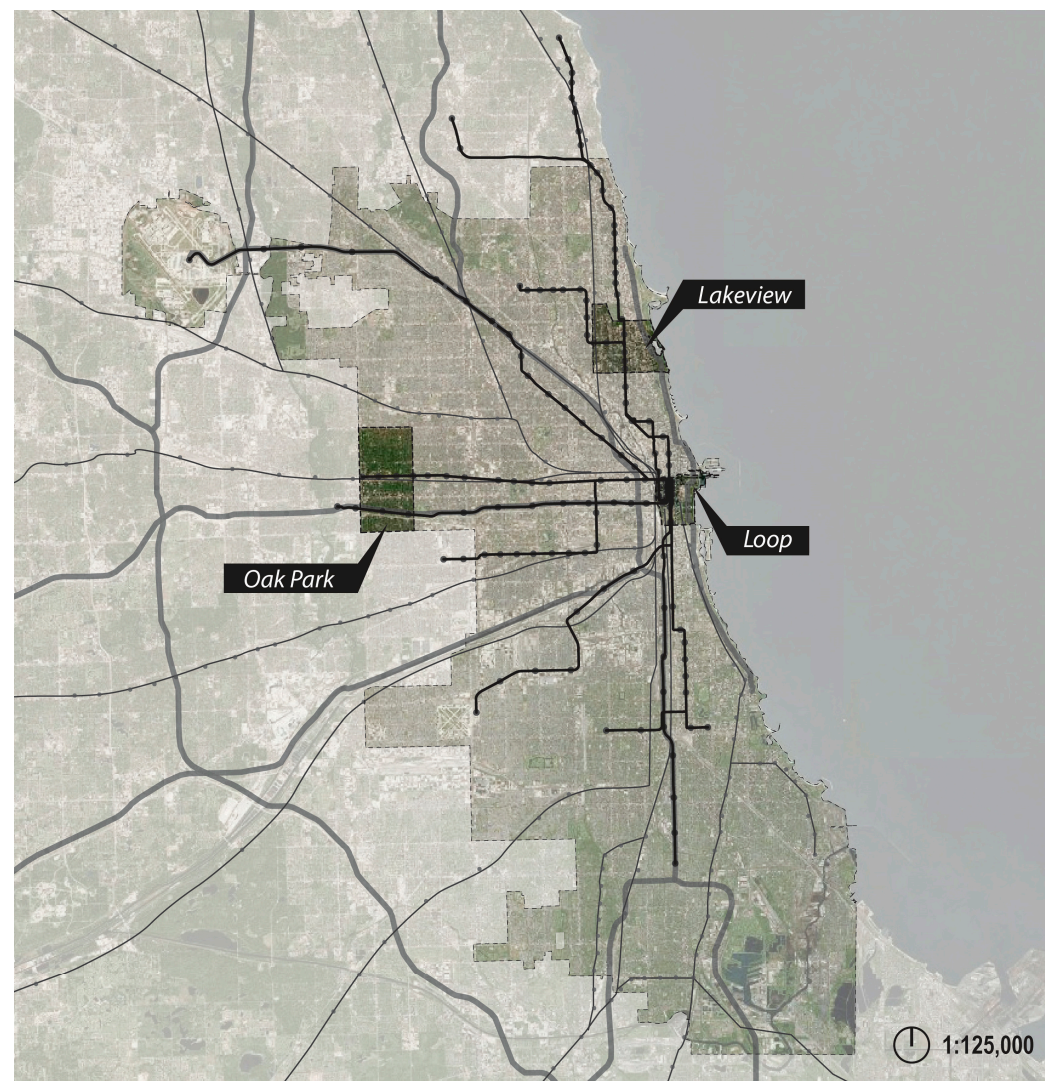

Figure 1. Study case locations relative to central Chicago and its major transportation systems.

\subsection{Case Study Set 1: Downtown High-Rise Residential Towers in Chicago, IL, USA}

The four downtown residential towers are located in areas of relatively high urban density and are served by numerous forms of public transportation (see Figure 2). These four residential towers were chosen for convenience based on the positive response by their developers, architects, and management companies. However, their locations generally represent two distinct areas of downtown Chicago high-rise residential life. The Aqua Tower and the Legacy at Millennium Park are both located in the downtown Chicago Loop (population density: 7200 people $/ \mathrm{km}^{2}$ ). The 73 -story Legacy at Millennium Park is located in the heart of a central business district of the Chicago Loop, facing eastward to Millennium Park and Lake Michigan. The 86-story Aqua Tower is located in Lakeshore East, a master-planned mixed-use urban development comprising apartments, condos, luxury townhomes, shops, and a six-acre park as the neighborhood's centerpiece. The 27-story Commonwealth Plaza (comprising two towers) is located on the edge of the Lakeview and Lincoln Park neighborhoods (Lakeview population density: 12,000 people $/ \mathrm{km}^{2}$ ), approximately $8 \mathrm{~km}$ north of the downtown Chicago Loop $[19,20]$. These are two of the highest density residential neighborhoods in the City of Chicago. These residential towers were also chosen because they included both relatively new and older existing construction: both the Aqua and Legacy towers were recently constructed (2009-2010), while the Commonwealth towers were built in 1956. 

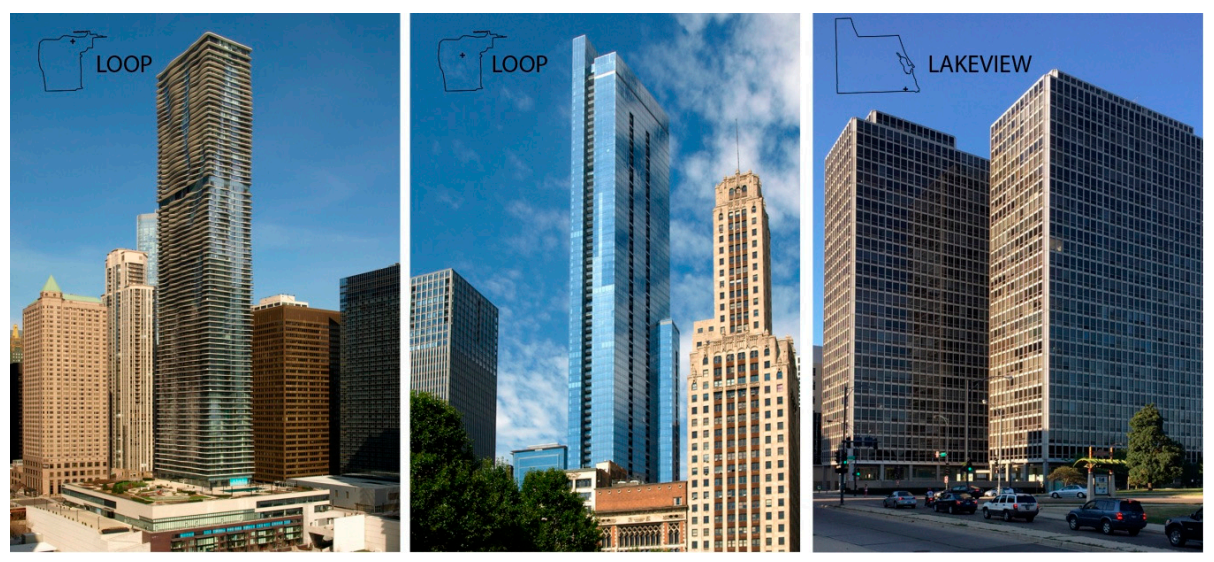

Figure 2. The high-rise residential buildings in downtown Chicago (left to right): Aqua Tower, Commonwealth Plaza and the Legacy at Millennium Park, Chicago. Image Source: CTBUH.

\subsection{Case Study Set 2: Suburban Low-Rise Residences in Oak Park, IL, USA}

The Village of Oak Park, IL was chosen as the representative suburban low-rise residential area for comparison to the downtown high-rise towers. The location was also selected for convenience, in part because of the strong support of our study displayed by the area's leadership. Oak Park (population density: 4262 people $/ \mathrm{km}^{2}$ ) is located approximately $14 \mathrm{~km}$ from Chicago's city center [20]. As an inner suburban neighborhood, Oak Park constitutes a relatively dense mix of single-family homes and apartments, with a relatively walkable environment. It is also accessible to much of Chicagoland's public transportation systems, including the Chicago Transit Authority (CTA) green and blue elevated train and subway lines and the regional Metra train lines. Because of this connection to public transit, Oak Park is considered distinctly suburban, rather than exurban like many of Chicago's other surrounding towns (e.g., Aurora or Naperville, IL, USA). Figure 3 shows the different urban layouts of the surrounding communities of the downtown high-rise and suburban low-rise cases in this research.
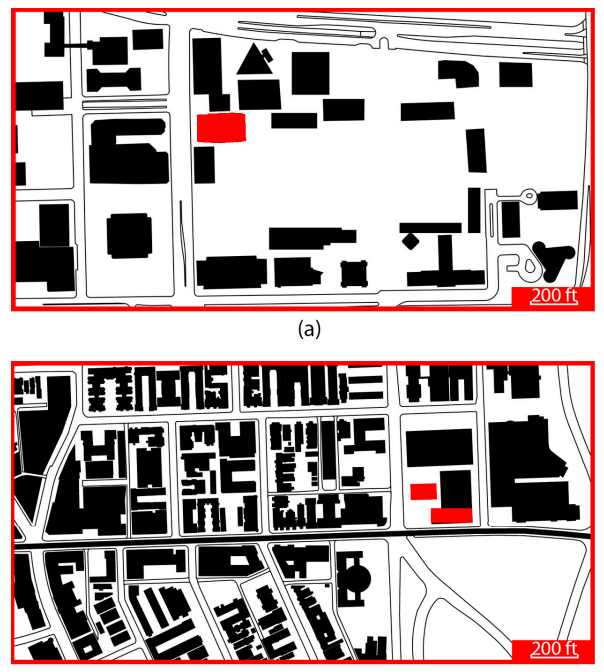

(c)

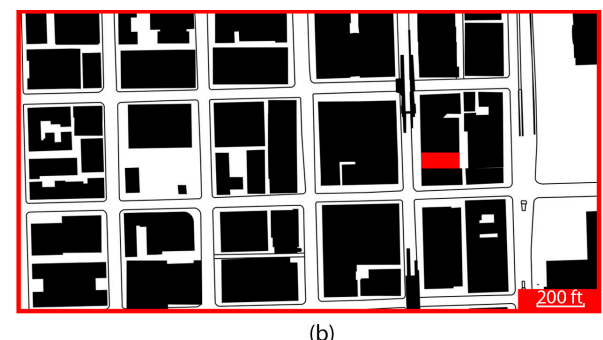

(b)

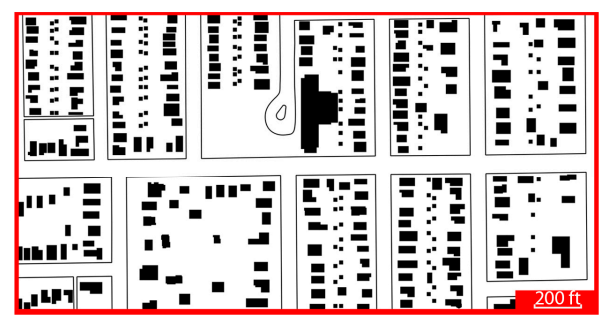

(d)

Figure 3. The surrounding community layouts (shown in red) of the downtown high-rise cases and a typical community's layout of the suburban low-rise buildings in this research. (a) Aqua Tower (downtown high-rise case); (b) Legacy at Millennium Park (downtown high-rise case); (c) Commonwealth Plaza (downtown high-rise case); (d) Oak Park (suburban low-rise cases). 


\subsection{Data Collection}

Operational building energy data and personal and household travel characteristics were collected via a comprehensive online survey created using SurveyGizmo. The research approach and the questionnaire were reviewed and approved by the Illinois Institute of Technology Institutional Review Board (IRB) via an expedited procedure. The study launched in Oak Park in February 2014, and in the Legacy at Millennium Park, Commonwealth Plaza, and Aqua Tower in March, May, and June 2014, respectively. The survey remained open for approximately three months in each case. Participants were recruited by a combination of activities, including promoting on the websites of the buildings and their respective community groups, emailing solicitations to residents, advertising in the building and/or community newsletters, posting flyers in the buildings, mailing letters to targeted households, and giving presentations at social and community events. Although it took approximately $45 \mathrm{~min}$ to complete the survey, over 1500 individuals were contacted directly, resulting in over 500 responses. The information from the online questionnaires completed by residents included:

- Demographics: each household member's age, gender, race, employment status, etc.

- Household information: annual income, ownership status, time of residence, age of residential buildings, etc.

- Residential building and unit information, including:

$>$ Downtown residential towers: unit type, room \#, ground floor area (GFA), floor \#, etc.

> Oak Park: building type, completion (year), structural and exterior wall material, floor \#, GFA, heating \& cooling system, outdoor feature, parking facility, etc.

- Owned vehicle/bicycle information: type, year, and distances traveled for various uses

- Travel behavior during a typical week: under each type of destination location (i.e., work, school, shopping, restaurant/entertainment, family/friends)

$>$ The collected data included frequency, travel time, modes of travel (i.e., walking, bicycling, automobile, bus, local CTA train, and regional Metra train), and distances traveled via each mode of travel

- Monthly utility usage: electric, gas, and water usage data for a 12-month period (participants could choose to upload their actual utility bills or fill out the actual usage for energy consumption from those bills)

\subsection{Data Analysis}

\subsubsection{Building Operational Energy (BOE)}

The amount of annual BOE was gathered from participants' utility bills (i.e., electric, gas, and, for the high-rise towers, chilled water [21-23] bills) collected from individual households in both downtown and Oak Park residences. The individual households in all locations were asked to either submit a copy of the most recent 12 months of utility bills, including electric and/or gas bills, or to enter the same data directly into the online survey. In addition, the management personnel at the downtown residential towers were asked to provide the most recent 12 months of utility bills, including electric, gas, and chilled water bills (if applicable), for the entire building. The whole-building bills for different residential towers covered different operational categories and serving areas. For example, the whole-building bills in the Legacy Building covered usage for all public areas and spaces outside individual units, plus usage of heated and chilled water within individual units. The whole-building bills in the Aqua Tower and Commonwealth Plaza covered usage in public areas as well as usage for cooking, heating, and heated and chilled water within individual units.

Because of differences in survey launch and completion times, the collected utility data did not fall in the exact same 12-month period for all households. Further, some of the collected utility data 
did not cover a full 12-month period. For example, the electricity usage data provided by Home A may have covered only 10 months from March 2013 to December 2013, while the natural gas usage data provided by Home B covered 11 months from May 2013 to April 2014. Therefore, two approaches were taken to provide a comparable 12-month dataset for as many homes as possible. First, the 12-month period of April 2013 to March 2014 was chosen as the common analysis period for annual BOE use because it was the period of time that contained the largest number of overlapping utility bill responses. Second, any missing data on monthly energy use for individual homes during any remaining months in this 12-month period were estimated by simple and/or multiple linear regression models between monthly energy use, monthly cooling degree days (CDD), and/or monthly heating degree days (HDD). The regressions were constructed using only the months for which there were utility bill data. The approach was considered appropriate because heating and cooling end-uses account for nearly half of the annual energy use in a typical U.S. home, making space conditioning the largest energy expense for most homes [24]. Only those buildings/households that provided at least eight months of energy usage data across all the applicable energy source types (i.e., electric, gas, and chilled water where applicable) were included for the regression analysis.

For the cases that used electricity for cooling and gas for heating, a linear regression model was used to predict the missing electricity usage associated with CDD, and another linear regression model was used to predict the missing gas usage associated with HDD. For the downtown residential towers that use chilled water provided and delivered by the city's district chilled water system for cooling, a linear regression model was used to predict the missing chilled water usage associated only with CDD. For the cases that used electricity for both cooling and heating, a multiple linear regression model was used to predict the missing electric usage associated with both CDD and HDD.

Site energy use data (i.e., the energy consumed directly at the buildings) were then converted into source (i.e., primary) energy use for the analysis herein. Source energy is the sum of the energy consumed at a facility and the energy required to extract, convert, and transport that useful energy to the facility [25] (p. 3). The various site energy metrics from the collected utility bills (i.e., " $\mathrm{kWh}$ " for electricity bills, "therm" for gas bills, and "ton-hour" for chilled water bills) were converted to source energy (MJ) using Equations (1)-(3):

$$
\begin{aligned}
& \text { Electric : } 1 \mathrm{MJ}_{\text {source }}=1 \mathrm{kWh} \text { site } \times 3.6 \mathrm{MJ} / \mathrm{kWh} \times 3.167 \mathrm{MJ}_{\text {source }} / \mathrm{MJ}_{\text {site }} \\
& \text { Natural Gas : } 1 \mathrm{MJ}_{\text {source }}=1 \text { therm }{ }_{\text {site }} \times 105.5 \mathrm{MJ} / \text { therm } \times 1.084 \mathrm{MJ}_{\text {source }} / \mathrm{MJ}_{\text {site }} \\
& \text { Chilled Water : } 1 \mathrm{MJ}_{\text {source }}=\left(1 \text { ton-hour } \mathrm{s}_{\text {site }} \times 12.66 \mathrm{MJ} / \text { ton-hour } \times 3.167 \mathrm{MJ}_{\text {source }} / \mathrm{MJ}_{\text {site }}\right) / 6.1
\end{aligned}
$$

In Equation (1), 3.6 converts from $\mathrm{kWh}$ to $\mathrm{MJ}$ and 3.167 converts site energy to source energy for grid electricity in Chicago [26,27]. In Equation (2), 105.5 converts therms to MJ and 1.084 converts site energy to source energy for natural gas in Chicago [26,27]. In Equation (3), 12.66 converts ton-hours to MJ; 3.167 converts site energy to source energy for electricity in Chicago [22,26,27]; and 6.1 is the estimated coefficient of performance (COP) for the electric motor driven centrifugal chillers used by Thermal Chicago's downtown chilled water loop [28]. Unfortunately, the exact COP of the chillers was not available; a conservative estimate of 6.1 was used, as it is the COP for a baseline centrifugal chiller according to ASHRAE 90.1-2007 [29].

\subsubsection{Transportation Operational Energy (TOE)}

Next, TOE requirements for transportation and supporting infrastructure were quantified on both a per-household and a per-person basis across both urban and suburban scenarios. These data were based on actual travel data collected through the survey combined with data on vehicle fuel economy from FuelEconomy.gov [30] for personal vehicle use, as well as the transportation LCA database (tLCAdb) for public transit use and supporting infrastructure for all modes of travel [31-33]. The modes of transport included automobile, bus, CTA train (Chicago's combination of local subway 
and elevated rail trains), and Metra (the Chicago area's regional rail system). As Table 1 shows, the $\mathrm{OE}$ categories include vehicle operation, roadway/station lighting, station escalator operation, station train control, and others.

Table 1. Categories of operational energy analysis for transportation systems.

\begin{tabular}{|c|c|c|c|}
\hline OE Components & Automobile & Bus & CTA Train/Metra \\
\hline Vehicle & Overall operation & Propulsion Idling & $\begin{array}{l}\text { Propulsion Idling } \\
\text { Station Lighting; }\end{array}$ \\
\hline Infrastructure & Roadway Lighting & Roadway Lighting & $\begin{array}{l}\text { Station Parking Lighting; } \\
\text { Station Escalators operation; } \\
\text { Station Train Control }\end{array}$ \\
\hline
\end{tabular}

The online survey gathered information on the number, make/model, and year of automobiles owned by each household, as well as the annual vehicle miles traveled (VMT) by automobile. The average annual automobile OE per household in each study case was then calculated using Equation (4):

$$
\text { Avg.OE }=\frac{\sum_{i=1}^{n}\left(\frac{V M T_{i}}{M P G_{i}}\right)}{n} \times 0.133 \frac{G J_{\text {site }}}{\text { gallon }} \times 1.05 \frac{\mathrm{GJ}_{\text {source }}}{\mathrm{GJ}_{\text {site }}}
$$

In Equation (4), $n$ is the total number of households that reported their travel behavior in each study case; $V M T_{i}$ is the annual miles traveled by automobile by Household $i ; M P G_{i}$ is the average estimated fuel economy (miles per gallon) [30,34] of all of the automobiles reported by household $i$; 0.133 converts gallons of gasoline to gigajoules (GJ) based on the average energy density of the fuel [26,35]; and 1.05 converts gasoline from secondary energy to primary energy.

It should be noted that not all the survey takers who reported their detailed travel behavior provided the complete vehicle information (i.e., number, make/model, and/or year). In the absence of these data, assumptions were made based on each location to estimate the likely fuel economy of vehicles in each missing household. The average year of automobiles owned by the households in the Aqua Tower, Commonwealth Plaza, Legacy Building, and Oak Park was reported as 2008, 2006, 2010, and 2005, respectively. Also, larger vehicles (e.g., vans, minivans, and pickup trucks) accounted for a larger portion of vehicles in the Oak Park households than did smaller vehicles (e.g., sedans, hatchbacks, convertibles, and coupes). The opposite was true for vehicle owners in the downtown high-rise households (see Appendix A for more detailed data). Therefore, in the absence of information on vehicle make/model (and thus fuel economy), the most popular vehicles of the most appropriate type were assumed to be owned in each location. A 2008, 2006, and 2010 Toyota Camry, which was the best-selling passenger car in the corresponding years in the United States [36], was assumed as the vehicle type for those in high-rise households who did not report the complete vehicle information, while a 2005 Chevrolet TrailBlazer, which was the best-selling SUV in the United States in the same year [37], was assumed as the vehicle type for those Oak Park households who did not report complete vehicle information $[30,38]$.

Last, the annual vehicle OE per passenger miles traveled (PMT) via public transportation, including bus and light/heavy rail transit, and the annual transportation infrastructure OE per PMT, including automobile, bus, and light/heavy rail transit, were estimated using the transportation LCA database (tLCAdb) [31-33,39]. The resulting vehicle OE usage for bus, CTA train, and Metra train in Chicago were estimated to be 3.21, 1.04, and 1.02 MJ/PMT, respectively, and the resulting transportation infrastructure OE usage for automobile, bus, CTA train, and Metra train in Chicago was estimated to be $0.04,0.002,0.057$, and $0.246 \mathrm{MJ} / \mathrm{PMT}$, respectively. Total annual TOE was then estimated by multiplying these values by the annualized passenger miles traveled by each mode of transport reported in the online survey. 


\section{Results}

A large number of survey responses were received in both the high-rise and low-rise scenarios, as shown in Table 2. Individuals from nearly 1000 households were contacted in the downtown high-rise towers, resulting in 249 fully or partially completed surveys (response rate of 25\%). Over 560 low-rise households in Oak Park were initially contacted, resulting in 273 fully or partially completed surveys (response rate of $48 \%$ ). A similar number of both high-rise and low-rise households completed the survey, providing a robust dataset of over 500 responses for analysis, split approximately evenly between high-rise and low-rise households.

Table 2. Questionnaire response summary.

\begin{tabular}{|c|c|c|c|c|c|}
\hline \multirow[t]{2}{*}{ Response Summary } & \multirow[t]{2}{*}{ Aqua } & \multirow[t]{2}{*}{ Commonwealth } & \multirow[t]{2}{*}{ Legacy } & \multirow{2}{*}{$\begin{array}{c}\begin{array}{c}\text { Downtown } \\
\text { High-Rise }\end{array} \\
\text { Towers }\end{array}$} & \multirow{2}{*}{$\begin{array}{l}\text { Suburban } \\
\text { Low-Rise }\end{array}$} \\
\hline & & & & & \\
\hline No. of completed responses ${ }^{1}$ & 40 & 31 & 41 & 112 & 123 \\
\hline No. of partially completed responses & 29 & 32 & 76 & 137 & 150 \\
\hline No. of responses & 69 & 63 & 117 & 249 & 273 \\
\hline No. of households contacted directly & $264^{2}$ & 375 & 357 & 996 & $565^{3}$ \\
\hline Response rate & $26.1 \%$ & $16.8 \%$ & $32.8 \%$ & $25 \%$ & $48.3 \%$ \\
\hline
\end{tabular}

Notes: ${ }^{1}$ Considering the fact that not all questions were compulsory and the questionnaire was very time-consuming (approximate $45 \mathrm{~min}$ to complete), a 'Completed' questionnaire was defined as one where at least $60 \%$ of the questions were answered. A 'Partially Completed' questionnaire was defined as one where less than $60 \%$ of the questions were answered; ${ }^{2}$ The Aqua Tower features 18 floors of hotel space (334 rooms), 30 floors of apartments ( 474 units), and 25 stories of condominiums (264 units). Due to legal issues raised by the building owner and management, only condo residents (264) were able to participate in the survey; ${ }^{3}$ This was the number of households the research team reached out to via local events, presentations, local authorities, schools, personal connections, etc.

Table 3 outlines the basic characteristics of the two case study sets using data collected from the partially and fully completed surveys, as well as several other public data sources. In general, Oak Park residents were younger than downtown high-rise residents, and also had larger household sizes. Most of the low-rise Oak Park homes were older (built before 1950), while two of the downtown towers (Aqua and Legacy) were recently constructed (2009-2010) and one tower (Commonwealth) was built in 1956. In terms of neighborhood statistics, downtown Chicago residences indeed had a higher population density and greater accessibility to public transportation than Oak Park residences. Oak Park residences had a larger average ground floor area (GFA) than the downtown high-rise cases on a per-household basis, but a smaller average GFA than the Aqua Tower or Legacy Building on a per-person basis.

Table 3. Basic characteristics of the two case study sets.

\begin{tabular}{|c|c|c|c|c|c|}
\hline \multirow{2}{*}{ Characteristics } & \multicolumn{3}{|c|}{ Downtown High-Rise } & \multirow{2}{*}{$\begin{array}{l}\text { Total } \\
\text { Towers }\end{array}$} & \multirow{2}{*}{$\begin{array}{c}\text { Suburban Low-Rise } \\
\text { Oak Park }\end{array}$} \\
\hline & Aqua Tower & Legacy & Commonwealth Plaza & & \\
\hline \multicolumn{6}{|c|}{ Household $^{1}$} \\
\hline Avg. Resident Age (y) & 48.5 & 54.6 & 47.8 & 51.1 & 31.8 \\
\hline Avg. HH Size & 1.8 & 1.9 & 2.0 & 1.9 & 3.3 \\
\hline Avg. GFA/HH $\left(\mathrm{m}^{2}\right)$ & 132.0 & 181.1 & 128.2 & 147.1 & 226.4 \\
\hline Avg. GFA/person $\left(\mathrm{m}^{2}\right)$ & 73.3 & 95.3 & 64.1 & 77.4 & 68.6 \\
\hline Car Ownership/HH & 1.4 & 1.2 & 1 & 1.2 & 1.8 \\
\hline Car Ownership/person & 0.8 & 0.6 & 0.5 & 0.6 & 0.5 \\
\hline
\end{tabular}


Table 3. Cont.

\begin{tabular}{|c|c|c|c|c|c|}
\hline \multirow{2}{*}{ Characteristics } & \multicolumn{3}{|c|}{ Downtown High-Rise } & \multirow{2}{*}{$\begin{array}{l}\text { Total } \\
\text { Towers }\end{array}$} & \multirow{2}{*}{$\begin{array}{c}\text { Suburban Low-Rise } \\
\text { Oak Park }\end{array}$} \\
\hline & Aqua Tower & Legacy & Commonwealth Plaza & & \\
\hline \multicolumn{6}{|c|}{ Building $^{2}$} \\
\hline Completion Year & 2010 & 2009 & 1956 & $\mathrm{~N} / \mathrm{A}$ & $\begin{array}{c}71.9 \% \text { built before } 1950 \\
24.7 \% \text { built } 1950-1999 \\
3.4 \% \text { built after } 2000\end{array}$ \\
\hline Height & $250 \mathrm{~m}$ & $262 \mathrm{~m}$ & $77 \mathrm{~m}$ & $\mathrm{~N} / \mathrm{A}$ & Typically $10 \mathrm{~m}$ or lower \\
\hline \# of Floors & 86 & 73 & 27 & & Typically $1-3$ \\
\hline \# of Units & 738 & 357 & 375 & $\mathrm{~N} / \mathrm{A}$ & Typically 1 per abode \\
\hline Structural Material & Concrete & Concrete & Steel/Concrete & $\mathrm{N} / \mathrm{A}$ & $\begin{array}{l}\text { Wood Frame or Stone } \\
\text { or Brick }\end{array}$ \\
\hline \# of Available Parking Spaces & 1271 & 449 & 293 & $\mathrm{~N} / \mathrm{A}$ & $\mathrm{N} / \mathrm{A}$ \\
\hline $\begin{array}{c}\text { \# of Available Parking } \\
\text { Spaces/Unit }\end{array}$ & 1.7 & 1.3 & 0.8 & 1.4 & $\mathrm{~N} / \mathrm{A}$ \\
\hline Neighborhood ${ }^{3}$ & \multicolumn{2}{|c|}{ Loop } & Lakeview & $\mathrm{N} / \mathrm{A}$ & Oak Park \\
\hline Neighborhood Population & \multicolumn{2}{|c|}{22,655} & 64,631 & $\mathrm{~N} / \mathrm{A}$ & 51,781 \\
\hline Neighborhood Density & \multicolumn{2}{|c|}{$7200 / \mathrm{km}^{2}$} & $12,000 / \mathrm{km}^{2}$ & $\mathrm{~N} / \mathrm{A}$ & $4262 / \mathrm{km}^{2}$ \\
\hline Distance to Chicago Loop & \multicolumn{2}{|c|}{ Walkable } & $6 \mathrm{~km}$ (average) & $\mathrm{N} / \mathrm{A}$ & 11-16 km (average) \\
\hline $\begin{array}{l}\text { Public Transport System in } \\
\text { Reasonable Walking Distance }\end{array}$ & \multicolumn{2}{|c|}{$\begin{array}{c}\text { All CTA Lines, All Metra Lines \& } \\
\text { Multiple Bus Lines }\end{array}$} & $\begin{array}{l}\text { CTA Red, Purple and } \\
\text { Brown Lines, Metra } \\
\text { UP-N Line \& Multiple } \\
\text { Bus Lines }\end{array}$ & $\mathrm{N} / \mathrm{A}$ & $\begin{array}{c}\text { Green \& Blue CTA lines, } \\
\text { Metra UP-West Line \& } \\
\text { Pace Buses }\end{array}$ \\
\hline
\end{tabular}

Notes: ${ }^{1}$ Data source: the survey completed by the households across all the cases; ${ }^{2}$ Data source: Building management companies, CTBUH Skyscraper Center [19] \& U.S. Census Bureau [20]; ${ }^{3}$ Data source: U.S. Census Bureau [20] \& Chicago Metropolitan Agency for Planning (CMAP) [40].

\subsection{Building Operational Energy (BOE)}

\subsubsection{Building Operational Energy (BOE) Analysis of Suburban Low-Rise Residential Buildings}

The total annual BOE for Oak Park households was calculated based on their individual utility bills, which consisted of two parts: $\mathrm{BOE}$ via electricity use $\left(\mathrm{BOE}_{\mathrm{e}}\right)$ and $\mathrm{BOE}$ via natural gas use $\left(\mathrm{BOE}_{\mathrm{g}}\right)$. Site energy use for these two end-uses was converted to source energy use using Equations (1) and (2). Table 4 summarizes the combination of these two annual building BOE measures from April 2013 to March 2014 for the Oak Park households, normalized for floor area, per household, and per person. Appendix B provides full details on annual BOE for each home.

Table 4. Descriptive statistics of the estimated annual operational energy of Oak Park homes $(N=64)$.

\begin{tabular}{cccccc}
\hline $\begin{array}{c}\text { Summary } \\
\text { Statistic }\end{array}$ & BOE $_{\mathbf{e}} \mathbf{M J} / \mathbf{m}^{2} / \mathbf{y}$ & $\mathbf{B O E}_{\mathbf{g}} \mathbf{M J} / \mathbf{m}^{2} / \mathbf{y}$ & $\begin{array}{c}\text { Total BOE } \\
\mathbf{M J} / \mathbf{m}^{2} / \mathbf{y}\end{array}$ & $\begin{array}{c}\text { Total BOE } \\
\text { GJ/HH/y }\end{array}$ & $\begin{array}{c}\text { Total BOE } \\
\text { GJ/person/y }\end{array}$ \\
\hline Minimum & 76.9 & 0.0 & 626.0 & 55.2 & 27.6 \\
Maximum & 1760.2 & 2257.3 & 4017.5 & 1306.3 & 579.9 \\
Mean & 661.0 & 1077.0 & 1737.9 & 393.2 & 120.7 \\
Std Dev & 368.6 & 415.8 & 624.8 & 214.9 & 84.7 \\
\hline
\end{tabular}

The average annual BOE (on a source energy basis) of the Oak Park low-rise residential buildings $(\mathrm{N}=64)$ was estimated to be $1738 \mathrm{MJ} / \mathrm{m}^{2} /$ year (standard deviation $=624.8 \mathrm{MJ} / \mathrm{m}^{2} /$ year), which included an average of $661 \mathrm{MJ} / \mathrm{m}^{2} /$ year for electricity $\left(\mathrm{BOE}_{\mathrm{e}}\right)$ and $1077 \mathrm{MJ} / \mathrm{m}^{2} /$ year for natural gas $\left(\mathrm{BOE}_{\mathrm{g}}\right)$. On a per-household and per-person basis, the Oak Park low-rise residences consumed approximately $393 \mathrm{GJ} / \mathrm{HH} /$ year (standard deviation $=214.9 \mathrm{GJ} / \mathrm{HH} /$ year) and $121 \mathrm{GJ} /$ person/year (standard deviation $=84.6 \mathrm{GJ} /$ person/year), respectively. There was a wide distribution in total $\mathrm{BOE}$, ranging from a minimum of $626 \mathrm{MJ} / \mathrm{m}^{2} /$ year to a maximum of $4018 \mathrm{MJ} / \mathrm{m}^{2} /$ year.

\subsubsection{Building Operational Energy (BOE) Analysis of Downtown High-Rise Residential Buildings}

Unlike the Oak Park low-rise homes, which all had individual utility bills, the total BOE for the Chicago downtown high-rise residences consisted of two parts: the BOE via electricity use [41] 
paid by the individual units $\left(\mathrm{BOE}_{\mathrm{i}}\right)$ and the $\mathrm{BOE}$ via electricity, gas, and/or chilled water paid by the building management $\left(\mathrm{BOE}_{\mathrm{b}}\right)$. The Aqua Tower was unfortunately excluded from the BOE analysis because the energy usage data received from its building management was too limited to be used to conduct a reasonable BOE analysis. The Aqua Tower is a mixed-use building including condominiums, apartments, and hotel spaces, with all of the amenities accessible to all permanent and temporary residents. Unfortunately, their whole-building bills reflected usage for the entire building, and could not be broken down into the three space types and thus permanent condominium residents could not be assigned individual unit energy use.

Both source energy and site energy use were examined since the energy sources used for cooling and heating were very different in the Commonwealth Plaza and Legacy Building. The Commonwealth Plaza uses gas heating and electric cooling, but the Legacy Building uses electricity for both heating and cooling (the gas bills of the Legacy Building are only for ranges and fireplaces in the lobby). Appendix $\mathrm{C}$ provides detailed $\mathrm{BOE}_{\mathrm{b}}$ data for both high-rise buildings. The total annual source $\mathrm{BOE}$ use paid for by the building management (Source BOE ${ }_{b}$ ) from April 2013 to March 2014 for the Commonwealth Plaza is estimated to be $1569 \mathrm{MJ} / \mathrm{m}^{2} /$ year, which is about $74.6 \%$ of the Legacy at 2105 $\mathrm{MJ} / \mathrm{m}^{2} /$ year. However, the result is opposite when considering site energy alone. The total annual site $\mathrm{BOE}$ use paid for by the building management $\left(\mathrm{Site}_{\mathrm{BOE}}\right)$ of the Commonwealth Plaza is estimated to be $1160 \mathrm{MJ} / \mathrm{m}^{2} /$ year, which is about $23 \%$ more than the Legacy at $943 \mathrm{MJ} / \mathrm{m}^{2} /$ year. This large discrepancy is due to source-to-site conversion efficiencies for electricity generation.

Table 5 summarizes the total annual BOE estimated for downtown high-rise households (on the basis of both site and source energy), calculated as a sum of $\mathrm{BOE}_{\mathrm{b}}$ and $\mathrm{BOE}_{\mathrm{i}}$. Appendix $\mathrm{D}$ provides detailed annual BOE data for each home in Commonwealth Plaza (C\#) and the Legacy Building (L\#) from April 2013 to March 2014. The average annual source OE for the downtown high-rise residential buildings $(N=42)$ was estimated to be $2520 \mathrm{MJ} / \mathrm{m}^{2} /$ year (standard deviation $=615.2 \mathrm{MJ} / \mathrm{m}^{2} /$ year). On a per-household and per-person basis, the downtown high-rise residential buildings were estimated to consume $388 \mathrm{GJ} / \mathrm{HH} /$ year (standard deviation $=283.8 \mathrm{GJ} / \mathrm{HH} /$ year) and $226 \mathrm{GJ} /$ person/year (standard deviation $=152.4 \mathrm{GJ} /$ person $/$ year) .

Table 5. Descriptive statistics of the estimated total annual operational energy of downtown high-rise homes $(N=42)$.

\begin{tabular}{|c|c|c|c|c|c|c|}
\hline $\begin{array}{l}\text { Summary } \\
\text { Statistic }\end{array}$ & $\begin{array}{l}\text { Site BOE } \\
\mathrm{MJ} / \mathrm{m}^{2} / \mathrm{y}\end{array}$ & $\begin{array}{c}\text { Source BOE } \\
\mathrm{MJ} / \mathrm{m}^{2} / \mathrm{y}\end{array}$ & $\begin{array}{l}\text { Site BOE } \\
\text { GJ/HH/y }\end{array}$ & $\begin{array}{c}\text { Source BOE } \\
\text { GJ/HH/y }\end{array}$ & $\begin{array}{c}\text { Site BOE } \\
\text { GJ/person/y }\end{array}$ & $\begin{array}{l}\text { Source BOE } \\
\text { GJ/person/y }\end{array}$ \\
\hline \multicolumn{7}{|c|}{ Commonwealth Plaza $(N=20)$} \\
\hline Minimum & 1218.8 & 1756.5 & 66.6 & 113.3 & 28.7 & 44.0 \\
\hline Maximum & 1440.2 & 2457.6 & 356.4 & 581.6 & 211.9 & 319.2 \\
\hline Mean & 1289.9 & 1981.8 & 155.6 & 238.4 & 97.5 & 148.5 \\
\hline Std Dev & 61.5 & 194.8 & 71.9 & 112.8 & 48.8 & 72.2 \\
\hline \multicolumn{7}{|c|}{ Legacy Building $(N=22)$} \\
\hline Minimum & 1050.7 & 2445.0 & 106.0 & 255.7 & 53.0 & 127.9 \\
\hline Maximum & 1577.3 & 4112.8 & 788.2 & $1,838.7$ & 394.1 & 919.4 \\
\hline Mean & 1228.6 & 3008.5 & 215.9 & 524.9 & 122.0 & 296.1 \\
\hline Std Dev & 133.5 & 422.8 & 138.9 & 323.7 & 74.2 & 172.5 \\
\hline \multicolumn{7}{|c|}{ Downtown Tower Average $(N=42)$} \\
\hline Minimum & 1050.7 & 1756.5 & 66.6 & 113.3 & 28.7 & 44.0 \\
\hline Maximum & 1577.3 & 4112.8 & 788.2 & 1838.7 & 394.1 & 919.4 \\
\hline Mean & 1257.8 & 2519.6 & 187.2 & 388.4 & 110.3 & 225.8 \\
\hline Std Dev & 108.8 & 615.2 & 114.9 & 283.8 & 63.8 & 152.4 \\
\hline
\end{tabular}

Figures 4 and 5 show the distributions of both source and site annual energy use for the Commonwealth Plaza $(N=20)$ and Legacy Building $(N=22)$. Compared to the older Commonwealth Plaza (built in 1956), the newer Legacy Building (built in 2010) is widely assumed to be more energy efficient based on its many energy-saving features such as a high-performance curtain wall and having 
a connection to the city's district chilled water system [42,43]. However, the Legacy Building was estimated to consume $1229 \mathrm{MJ} / \mathrm{m}^{2} /$ year (standard deviation $=133.5 \mathrm{MJ} / \mathrm{m}^{2} /$ year) on a site BOE basis, on average, which is only slightly less than the average site energy use in the much older Commonwealth Plaza (1290 MJ $/ \mathrm{m}^{2} /$ year, standard deviation $=61.5 \mathrm{MJ} / \mathrm{m}^{2} /$ year). This result might indicate that the BOE saved by the energy saving features in the Legacy Building is offset by the energy consumed by its greater amenities (i.e., indoor pool, whirlpool spa, fitness center, etc.). Moreover, when comparing the source BOE use, the Commonwealth Plaza is predicted to consume $1982 \mathrm{MJ} / \mathrm{m}^{2} /$ year (standard deviation $=194.8 \mathrm{MJ} / \mathrm{m}^{2} /$ year), on average, which is approximately $34 \%$ less than the newer Legacy Building at $3001 \mathrm{MJ} / \mathrm{m}^{2} /$ year (standard deviation $=422.8 \mathrm{MJ} / \mathrm{m}^{2} /$ year). This heightened discrepancy is clearly due to the use of electric heating in the Legacy instead of natural gas heating in the Commonwealth Plaza.

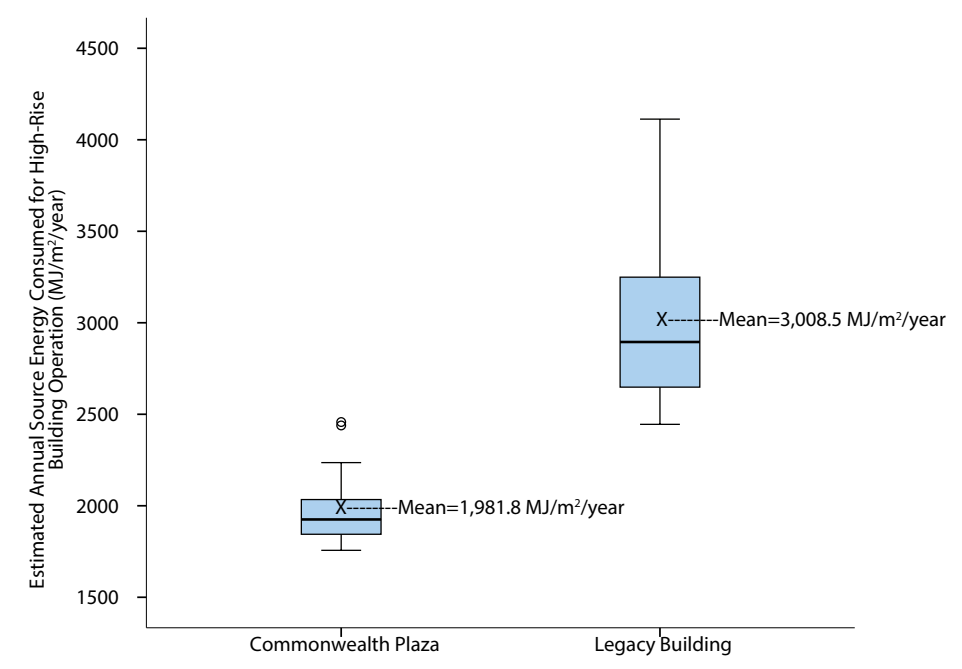

Figure 4. Annual source energy consumed for building operation of the high-rise Commonwealth Plaza and Legacy buildings (MJ/ $\mathrm{m}^{2} /$ year).

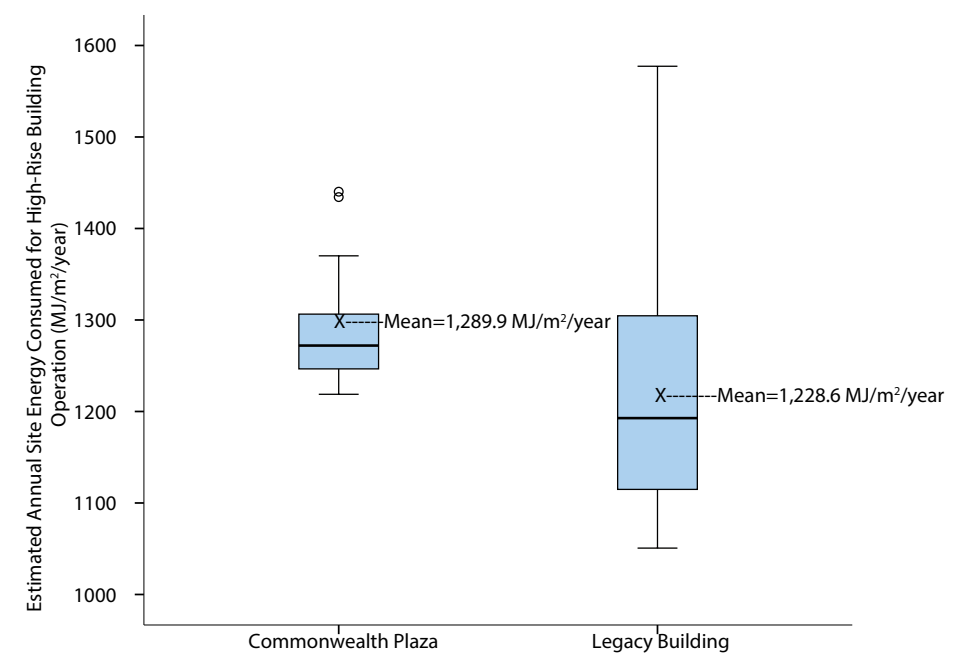

Figure 5. Annual site energy consumed for building operation of the high-rise Commonwealth Plaza and Legacy buildings (MJ/ $\mathrm{m}^{2} /$ year).

3.1.3. Building Operational Energy (BOE) Comparison of High-Rise vs. Low-Rise Residential Buildings

As shown in Tables 4 and 5, the downtown residential towers are predicted to consume $2520 \mathrm{MJ} / \mathrm{m}^{2} /$ year source BOE, on average, which is approximately $45 \%$ greater than the suburban 
low-rise residential buildings (with an average of $1738 \mathrm{MJ} / \mathrm{m}^{2} /$ year). However, these differences are smaller when averaged on a per-household basis because the Oak Park residences are much larger than the high-rise units (Table 2). The downtown residential towers are estimated to consume $388 \mathrm{GJ} / \mathrm{HH} /$ year in source BOE, which is actually slightly less than the suburban low-rise residences at $393 \mathrm{GJ} / \mathrm{HH} /$ year. However, on a per-person basis, the high-rise units are estimated to consume $226 \mathrm{GJ} /$ person/year in source OE, which is $\sim 87 \%$ greater than the suburban low-rise residential buildings at $121 \mathrm{GJ} /$ person/year.

Figures 6-8 graphically compare the distribution of BOE in downtown high-rise $(N=42)$ and suburban low-rise $(N=64)$ homes, presented on a floor area, per-household, and per-person basis, respectively. Full data for the detailed annual BOE by each home are provided in Appendixs A and C. Differences in annual source BOE between the downtown high-rise and the suburban low-rise home groups were statistically significant on both a floor area and a per-person basis $(p<0.0001$ according to nonparametric Mann-Whitney U tests) (see Table 6). However, differences in annual source BOE on a per-household basis were not statistically significant $(p=0.552)$.

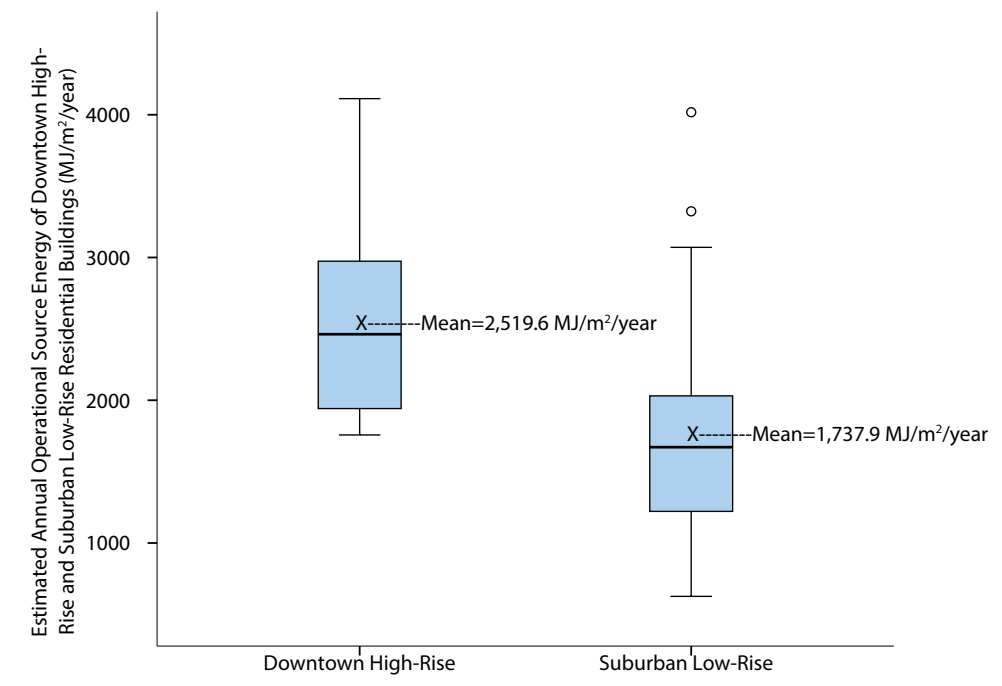

Figure 6. Annual source operational energy use of downtown high-rise residences in Chicago, IL and suburban low-rise residences in Oak Park, IL on a floor area basis (MJ/ $\mathrm{m}^{2} /$ year).

These data demonstrate that households in this sample of downtown high-rise residential buildings in Chicago, IL actually consume more annual building OE (on a source energy basis) than low-rise residences in suburban Oak Park, IL, both on a floor area and per-person basis. However, the annual building source $\mathrm{OE}$ use is comparable on a per-household basis (i.e., Oak Park low-rise residences consume only $\sim 1.2 \%$ more source BOE per household than the downtown high-rise residences, on average). It should be noted that these findings are limited to the specific building types and household demographics surveyed here. For example, super-tall and luxury residential buildings such as the Legacy Building likely require more BOE for elevators, pumps, fans, on-site management services, and other amenities than a conventional high-rise building. Also, the fact that fewer people live in a relatively larger size unit in downtown high-rise cases resulted in greater BOE use on a per-person basis (i.e., the average GFA per person in the Legacy Building is 1.4 times larger than in Oak Park, as shown in Table 2). However, a larger household (HH) size in the Oak Park homes resulted in less $\mathrm{OE}$ consumption on a per-person basis (i.e., the average $\mathrm{HH}$ size in Oak Park is 3.3 in this study, but only 2.4 across the entire Oak Park neighborhood [40]). In addition, $37.8 \%$ of the household members in the Oak Park residences in this study were children under 18 (compared to only $5.5 \%$ in the downtown residences), who might not require as much BOE as a typical adult does. These factors are explored in more detail in the next section. Given these limitations, annual $\mathrm{OE}$ use 
on both a per-household and a per-person basis were chosen for the final BOE comparisons after taking into account the energy use associated not only with buildings but also with transportation and supporting transportation infrastructure.

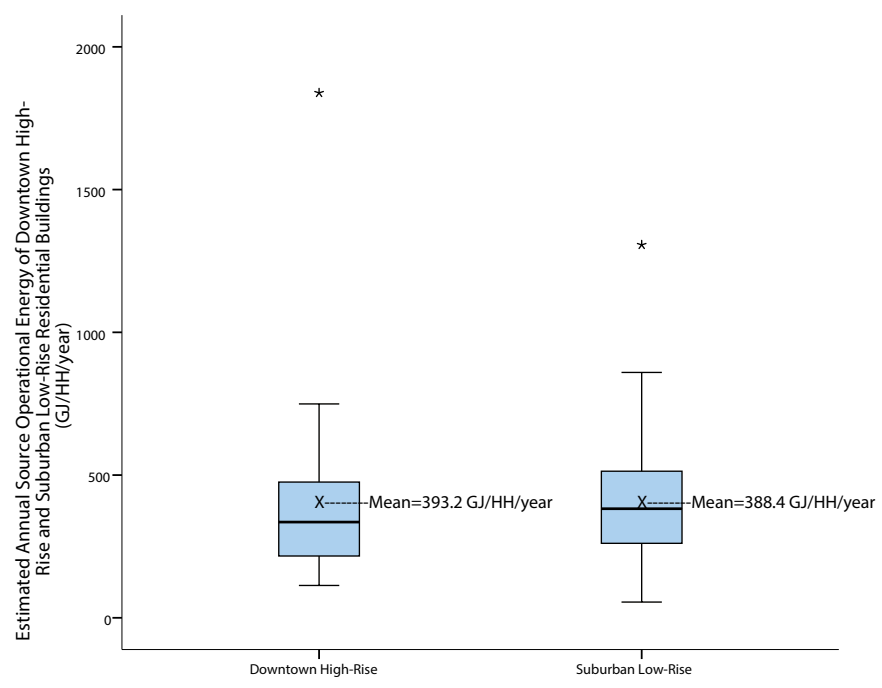

Figure 7. Annual source operational energy use of downtown high-rise residences in Chicago, IL and suburban low-rise residences in Oak Park, IL on a per-household basis (GJ/HH/year).

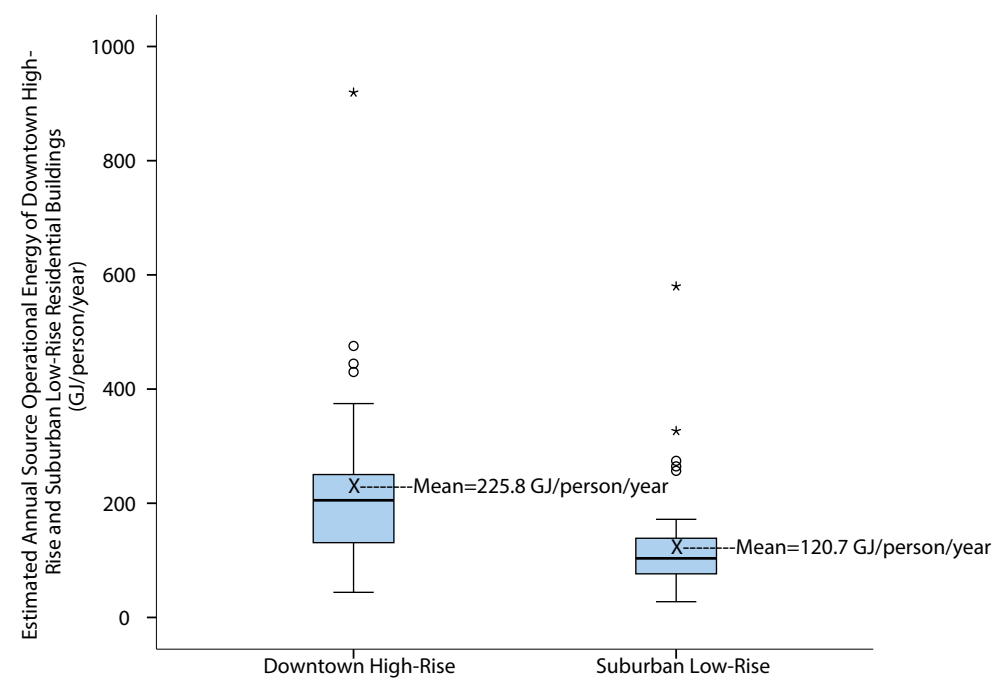

Figure 8. Annual source operational energy use of downtown high-rise residences in Chicago, IL and suburban low-rise residences in Oak Park, IL on a per-person basis (GJ/person/year).

Table 6. Mann-Whitney U test statistics for the downtown high-rise and suburban low-rise homes.

\begin{tabular}{cccc}
\hline Test Statistics & Source BOE MJ/m²/y & Source BOE GJ/HH/y & Source BOE GJ/person/y \\
\hline Mann-Whitney U & 432 & 1252 & 576 \\
Wilcoxon W & 2512 & 2155 & 2656 \\
Z & -5.891 & -0.594 & -4.961 \\
Asymp. Sig. (2-tailed) & 0.000 & 0.552 & 0.000 \\
\hline
\end{tabular}

\subsubsection{Building Operational Energy (BOE) Correlation Analysis}

It is important to analyze correlations between $\mathrm{BOE}$ and several characteristics of the households and residential buildings surveyed herein. Four variables were evaluated for their influence on the variability in $\mathrm{BOE}$, including the age of residential buildings (ARB, in years), annual $\mathrm{HH}$ income, $\mathrm{HH}$ size, and GFA/HH (in $\mathrm{m}^{2}$ ). Linear correlations were first conducted between BOE and each 
of these variables, treating high-rise and low-rise scenarios separately. Annual HH income was grouped into 12 different income ranges in the survey, and thus was coded in the correlation analysis as 1 for "Under $\$ 50,000$ ", 2 for " $\$ 50,000-\$ 59,999$ ", 3 for “ $\$ 60,000-\$ 69,999$ ", 4 for " $\$ 70,000-\$ 79,999$ ", 5 for “ $\$ 80,000-\$ 89,999$ ", 6 for $\$ 90,000-\$ 99,999$ ", 7 for “ $\$ 100,000-\$ 124,999$ ", 8 for “ $\$ 125,000-\$ 149,999$ ", 9 for $\$ 150,000-\$ 199,999$ ", 10 for “\$200,000-\$249,999", 11 for “ $\$ 250,000-\$ 299,999$ ", and 12 for " $\$ 300,000$ and over." ARB was excluded in the downtown high-rise scenarios because there were only two different ages of residential towers (i.e., the ages of Legacy Building and Commonwealth Plaza were 7 and 60 , respectively).

BOE per $\mathrm{HH}$ was not significantly correlated with annual HH income $\left(R^{2}=0.10\right)$ or $\mathrm{HH}$ size $\left(R^{2}=0.02\right)$ in the downtown high-rise cases $(N=42)$, but was strongly correlated with GFA/HH $\left(R^{2}=0.90\right)$. Similarly, BOE per person was not significantly correlated with annual HH income $\left(R^{2}=0.03\right)$ or HH size $\left(R^{2}=0.10\right)$ in the downtown high-rise cases $(N=42)$, but was correlated with GFA/HH $\left(R^{2}=0.66\right)$. Comparably, BOE per HH was not significantly correlated with ARB $\left(R^{2}=0.15\right)$ or HH size $\left(R^{2}=0.13\right)$ in the suburban low-rise cases $(N=64)$, and was only weakly correlated with annual HH income $\left(R^{2}=0.30\right)$. BOE per HH was moderately correlated with GFA/HH $\left(R^{2}=0.53\right)$ in the low-rise cases. Finally, BOE per person was not significantly correlated with ARB $\left(R^{2}=0.10\right)$, annual HH income $\left(R^{2}=0.01\right)$, HH size $\left(R^{2}=0.15\right)$, or GFA/HH $\left(R^{2}=0.26\right)$ in the suburban low-rise cases $(N=64)$. Further, annual HH income was similar across the two home types; the median income bracket was " $\$ 150,000-\$ 199,999$ " in both locations ( $p=0.80$ according to nonparametric Mann-Whitney $\mathrm{U}$ tests). These correlations clearly demonstrate that the most significant predictor of variability in BOE in both high-rise and low-rise cases is the size of the units or homes (i.e., GFA/HH). Annual HH income, $\mathrm{HH}$ size, and ARB only minimally impacted the BOE results. Therefore, it is not necessary to correct for any of these factors in subsequent analyses.

\subsection{Transportation Operational Energy (TOE)}

\subsubsection{Travel Behavior Analysis}

A comprehensive travel survey was included in the online survey to collect data on the type and number of automobiles owned and operated by each household, as well as their typical weekly travel behavior via all modes of transport for various destinations, including work, school, shopping, restaurant/entertainment, family/friends, and "other" (for the respondent to specify if applicable). These values were then extrapolated for a one-year period. The modes of travel include walking, bicycling, automobile, bus, local CTA train (i.e., the City of Chicago's combination of elevated rail and underground subway mass transit system), regional Metra train (similar to Amtrak), and others (if applicable). Table 7 summarizes the average annual distances traveled by all modes of transport to all destinations for both downtown and suburban homes, presented on both s per-household and s per-person basis.

Automobile travel was found to be the most widely used mode of transport in both study locations, and interestingly, it shared more than half of the total annual distance traveled by residents of both urban $(64.7 \%)$ and suburban $(57.1 \%)$ living scenarios. Regional Metra train travel was the second most widely used mode of transport for suburban low-rise residents ( $27.8 \%$ share), but was the least widely used mode of transport for downtown high-rise residents (only 2.1\% share). For the other public modes of transport, downtown high-rise residents relied on CTA trains slightly more than buses (CTA train shares were $7.1 \%$ vs. bus shares of $6.8 \%$ ), while suburban low-rise residents shared a similar usage rate of CTA trains (7.7\%) but had a very small usage rate of buses (1.3\%) [44]. 
Table 7. Average annual distances traveled by all the modes of transport, per household and per person, to all the destinations in the downtown high-rise and suburban low-rise scenarios.

\begin{tabular}{ccccccc}
\hline \multirow{2}{*}{$\begin{array}{c}\text { Mode of } \\
\text { Transport }\end{array}$} & \multicolumn{3}{c}{ Downtown High-Rise } & \multicolumn{3}{c}{ Suburban Low-Rise } \\
\cline { 2 - 7 } & $\mathbf{k m} / \mathbf{H H} / \mathbf{y}$ & $\mathbf{k m} /$ person/y & Percent of Total & $\mathbf{k m} / \mathbf{H H} / \mathbf{y}$ & $\mathbf{k m} / \mathbf{p e r s o n} / \mathbf{y}$ & Percent of Total \\
\hline Walking & 2293 & 1206 & $15.5 \%$ & 1914 & 579 & $5.3 \%$ \\
Bicycle & 416 & 219 & $2.8 \%$ & 253 & 77 & $0.7 \%$ \\
Automobile & 9595 & 2050 & $64.7 \%$ & 20,645 & 6256 & $57.1 \%$ \\
Bus & 1010 & 531 & $6.8 \%$ & 486 & 147 & $1.3 \%$ \\
CTA train & 1059 & 557 & $7.1 \%$ & 2786 & 843 & $7.7 \%$ \\
Metra train & 307 & 162 & $2.1 \%$ & 10,070 & 3051 & $27.8 \%$ \\
Other & 149 & 78 & $1.0 \%$ & 43 & 13 & $0.1 \%$ \\
\hline Total & 14,829 & 7803 & $100 \%$ & 36,197 & 10,966 & $100 \%$ \\
\hline
\end{tabular}

\subsubsection{Transportation Operational Energy (TOE)}

Table 8 shows the average annual source OE estimated for all modes of transport in both downtown and suburban locations. Automobile transport was the single largest transport use in both locations, accounting for over $90 \%$ of transportation OE in both cases. It was estimated to be 94.3 GJ per household per year in the low-rise Oak Park cases, which was approximately 2.8 times greater than in the Chicago downtown high-rises $(33.3 \mathrm{GJ} / \mathrm{HH} / \mathrm{y})$. On a per-person basis, the average annual source OE for automobile transport in Oak Park was calculated to be $28.6 \mathrm{GJ} /$ person/y, which was approximately 1.6 times greater than in the Chicago downtown high-rises (18.4 GJ/person/y). Transportation OE for regional Metra train travel was higher for the suburban low-rise residences (on both a per-household and a per-person basis), and was similar for local CTA train transit in both locations, although the total energy use of these modes was quite low overall. The average annual source $\mathrm{OE}$ for all modes of transportation was estimated to be $103.5 \mathrm{GJ} / \mathrm{HH} /$ year on a per-household basis in Oak Park, which was approximately 2.7 times greater than the Chicago downtown high-rise residences at $37.9 \mathrm{GJ} / \mathrm{HH} /$ year. Similarly, the average annual source OE for all modes of transportation was estimated to be $31.4 \mathrm{GJ} /$ person/year in Oak Park, which was approximately 1.6 times greater than in the downtown Chicago high-rise residences at $19.9 \mathrm{GJ} /$ person/year. Clearly, residents in the suburban low-rise cases studies herein used much more operational TOE than residents in the downtown high-rise cases, primarily because of greater per-person and per-household automobile travel, which is consistent with most previous literature [3,7,12].

Table 8. Average annual operational energy of automobile, bus, CTA train and Metra train transport across both urban high-rise and suburban low-rise scenarios on both a per-household and a per-person basis.

\begin{tabular}{ccccccc}
\hline \multirow{2}{*}{ Mode of Transport } & \multicolumn{3}{c}{ Downtown High-Rise } & \multicolumn{3}{c}{ Suburban Low-Rise } \\
\cline { 2 - 7 } & GJ/HH/y & GJ/person/y & Percent & GJ/HH/y & GJ/person/y & Percent \\
\hline Auto & 34.9 & 18.4 & $92.3 \%$ & 94.3 & 28.6 & $91.1 \%$ \\
Bus & 2.0 & 1.0 & $5.4 \%$ & 1.0 & 0.3 & $0.9 \%$ \\
$\begin{array}{c}\text { CTA Train (local) } \\
\text { Metra Train } \\
\text { (regional) }\end{array}$ & 0.7 & 0.4 & $1.8 \%$ & 1.8 & 0.6 & $1.8 \%$ \\
\hline Total & 0.2 & 0.1 & $0.5 \%$ & 6.4 & 2.0 & $6.2 \%$ \\
\hline
\end{tabular}

Table 9 summarizes the average annual source OE requirements of the supporting transportation infrastructure (i.e., for automobile, bus, local CTA train, and regional Metra train travel) estimated for downtown high-rise and suburban low-rise residences on both a per-household and a per-person basis. Data are taken directly from tLCAdb. 
Table 9. Estimates of operational energy of the supporting infrastructure for automobile, bus, CTA train, and Metra train travel from tLCAdb.

\begin{tabular}{ccccccc}
\hline \multirow{2}{*}{ Mode of Transport } & \multicolumn{3}{c}{ Downtown High-Rise } & \multicolumn{3}{c}{ Suburban Low-Rise } \\
\cline { 2 - 7 } & GJ/HH/y & GJ/person/y & Percent & GJ/HH/y & GJ/person/y & Percent \\
\hline Auto & 0.24 & 0.13 & $72.7 \%$ & 0.52 & 0.16 & $24.0 \%$ \\
Bus & 0.00 & 0.00 & $0.0 \%$ & 0.00 & 0.00 & $0.0 \%$ \\
CTA Train & 0.04 & 0.02 & $12.1 \%$ & 0.10 & 0.03 & $4.6 \%$ \\
Metra Train & 0.05 & 0.02 & $15.2 \%$ & 1.55 & 0.47 & $71.4 \%$ \\
\hline Total & 0.33 & 0.17 & $100 \%$ & 2.17 & 0.66 & $100 \%$ \\
\hline
\end{tabular}

The average annual $\mathrm{OE}$ for the transportation infrastructure in Oak Park was estimated to be $2.2 \mathrm{GJ} / \mathrm{HH} /$ year on a per-household basis, which was approximately 6.6 times greater than in the Chicago downtown high-rise residences ( $\sim .33 \mathrm{GJ} / \mathrm{HH} /$ year). Similarly, on a per-person basis, average annual $\mathrm{OE}$ for transportation infrastructure was estimated to be $0.66 \mathrm{GJ} /$ person/year in Oak Park, which was approximately 3.9 times greater than in the downtown Chicago high-rise residences at $0.17 \mathrm{GJ} /$ person/year. In the urban high-rise homes, infrastructure $\mathrm{OE}$ for automobile transport was the largest contributor to the total transportation infrastructure OE (share of $72.7 \%$ ), followed by infrastructure OE for Metra train (15.2\%) and CTA train (12.1\%) travel. In suburban low-rise homes, infrastructure $\mathrm{OE}$ for Metra train was the largest contributor to the total transportation infrastructure OE (share $71.4 \%$ ), followed by infrastructure OE for automobile travel (at $24 \%$ ).

\subsection{Comparison of Total Operational Energy for Buildings and Transportation}

Finally, the OE data for building, transportation, and supporting transportation infrastructure were combined to make a direct comparison of the total annual source energy requirements associated with typical residential life in both the downtown high-rise and suburban low-rise residences. Data are again presented on a per-household and a per-person basis (e.g., GJ/HH/year and GJ/person/year). As Table 10 and Figure 9 show, the average household in the downtown Chicago high-rise residences was estimated to account for approximately $427 \mathrm{GJ} / \mathrm{HH} /$ year in total source OE use, while those in Oak Park low-rise residences were estimated to account for approximately $499 \mathrm{GJ} / \mathrm{HH} /$ year, on average. Thus, the average source energy footprint of downtown high-rise residences was approximately $14 \%$ lower than suburban low-rise residences on a per-household basis. However, this direction of this difference was opposite when compared on a per-person basis: the average source $\mathrm{OE}$ use of those living in downtown Chicago high-rises was estimated to be approximately $246 \mathrm{GJ} /$ person/year compared to only $153 \mathrm{GJ} /$ person/year in Oak Park low-rise residences. Therefore, on a per-person basis, the average source energy footprint was approximately $61 \%$ higher for those living in the downtown high-rise residential buildings.

Table 10. Annual source operational energy use associated with residential life (including buildings, transportation, and transportation infrastructure) in the Chicago downtown high-rise and Oak Park low-rise residences.

\begin{tabular}{ccccccc}
\hline \multirow{2}{*}{ OE Categories } & \multicolumn{3}{c}{ Downtown High-Rise } & \multicolumn{3}{c}{ Suburban Low-Rise } \\
\cline { 2 - 7 } & GJ/HH/y & GJ/person/y & Percent & GJ/HH/y & GJ/person/y & Percent \\
\hline Building & 388.4 & 225.8 & $91.0 \%$ & 393.2 & 120.7 & $78.8 \%$ \\
Transportation & 37.9 & 19.9 & $8.9 \%$ & 103.5 & 31.4 & $20.8 \%$ \\
Transportation & 0.3 & 0.2 & $0.1 \%$ & 2.2 & 0.7 & $0.4 \%$ \\
Infrastructure & & 245.9 & $100 \%$ & 498.9 & 152.8 & $100 \%$ \\
\hline Total & 426.6 & & & & & \\
\hline
\end{tabular}




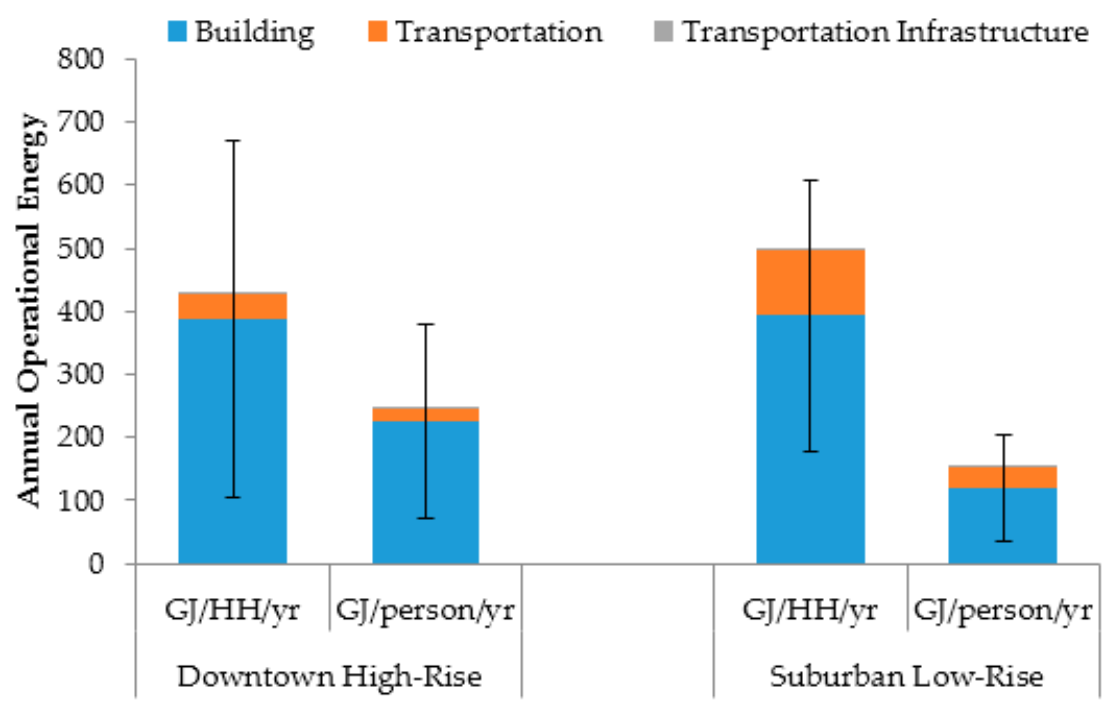

Figure 9. Average (standard deviation) operational source energy use associated with residential life (including buildings, transportation, and transportation infrastructure) in the Chicago downtown high-rise and Oak Park low-rise residences.

\section{Discussion}

\subsection{Comparison to Previous Studies}

The findings herein suggest that, when accounting for operational energy (OE) use by buildings, transportation, and transportation infrastructure across these two types of residential case studies, downtown high-rise living was estimated to account for approximately $14 \%$ less source OE use than suburban low-rise living on a per-household basis, on average, but approximately $61 \%$ more than suburban low-rise living on a per-person basis. This result is in conflict with some early studies such as Norman et al. [3], Perkins et al. [7], and Stephan et al. [10], in which OE for urban high density living was found to be $55 \%, 24 \%$, and $27 \%$ lower than in suburban low density living on a per-person basis, respectively. However, these results are generally in line with other studies such as Fuller et al. and Du et al. [11,12]. Fuller et al. [11] found that city-center living consumed approximately $33 \%$ more than inner-suburban low-density living. Similarly, Du et al. [12] found that downtown high-rise living (using only public data sources and data from the existing literature) consumed approximately $34 \%$ more than suburban low-rise living. Table 11 summarizes the OE results in these previous studies in more detail. 
Table 11. Annual operational energy comparison across previous studies.

\begin{tabular}{|c|c|c|c|c|c|c|c|c|c|c|c|c|}
\hline \multirow{2}{*}{ Previous Studies } & \multirow{2}{*}{ Location } & \multirow{2}{*}{$\begin{array}{l}\text { Urban } \\
\text { Pattern }\end{array}$} & \multirow{2}{*}{ Building Type } & \multirow{2}{*}{$\begin{array}{l}\text { HH } \\
\text { Size }\end{array}$} & \multirow{2}{*}{$\begin{array}{l}\text { Energy } \\
\text { Input }\end{array}$} & \multirow{2}{*}{$\begin{array}{c}\text { GFA/Person } \\
\left(\mathrm{m}^{2}\right)\end{array}$} & \multicolumn{2}{|c|}{ BOE } & \multicolumn{2}{|c|}{ TOE } & \multicolumn{2}{|c|}{ Total OE } \\
\hline & & & & & & & GJ/HH & GJ/person & GJ/HH & GJ/person & GJ/HH & GJ/person \\
\hline \multicolumn{13}{|c|}{ Urban high-density scenarios } \\
\hline Norman et al. (2006) [3] & $\begin{array}{l}\text { Toronto, } \\
\text { Canada }\end{array}$ & City center & 15-story high-rise & 1.8 & Unknown & 42.8 & 49.5 & 27.5 & 14.2 & 7.9 & 63.7 & 35.4 \\
\hline Perkins et al. (2009) [7] & $\begin{array}{l}\text { Adelaide } \\
\text { Australia }\end{array}$ & City center & 6-8-story mid-rise & 1.6 & Site & 17.5 & 32 & 20 & 13 & 8 & 45 & 28 \\
\hline Fuller et al. (2011) [11] ${ }^{1}$ & $\begin{array}{l}\text { Melbourne, } \\
\text { Australia }\end{array}$ & City center & 20-story high-rise & 2.1 & Source & 47.6 & 37.8 & 18 & 4.2 & 2 & 42 & 20 \\
\hline Stephan et al. (2013) [10] ${ }^{2}$ & $\begin{array}{l}\text { Brussels, } \\
\text { Belgium }\end{array}$ & City center & 10-story high-rise & 2 & Source & 40 & 50 & 25 & 28.8 & 14.4 & 78.8 & 39.4 \\
\hline Du et al. (2015) [12] & $\begin{array}{l}\text { Chicago, } \\
\text { USA }\end{array}$ & City center & 10-story high-rise & 1.6 & Source & 66 & 180.6 & 112.9 & 24.8 & 15.5 & 205.4 & 128.4 \\
\hline This study & $\begin{array}{l}\text { Chicago, } \\
\text { USA }\end{array}$ & City center & 27-86-story high-rise & 1.9 & Source & 77.4 & 388.4 & 225.8 & 38.2 & 20.1 & 426.6 & 245.9 \\
\hline \multicolumn{13}{|c|}{ Suburban low-density scenarios } \\
\hline Norman et al. (2006) [3] & $\begin{array}{l}\text { Toronto, } \\
\text { Canada }\end{array}$ & Outer suburb & Single-family & 3 & Unknown & 80.5 & 149.4 & 49.8 & 86.4 & 28.8 & 235.8 & 78.6 \\
\hline Perkins et al. (2009) [7] & $\begin{array}{l}\text { Adelaide } \\
\text { Australia }\end{array}$ & Inner suburb & 2-story terrace & 2 & Site & 113.5 & 27 & 14 & 46 & 23 & 73 & 37 \\
\hline Perkins et al. (2009) [7] & $\begin{array}{l}\text { Adelaide } \\
\text { Australia }\end{array}$ & Outer suburb & Single-family & 2.5 & Site & 204 & 36 & 13 & 132 & 48 & 168 & 61 \\
\hline Fuller et al. (2011) [11] ${ }^{1}$ & $\begin{array}{l}\text { Melbourne, } \\
\text { Australia }\end{array}$ & Inner suburb & Mid-rise & 1.6 & Source & 40 & 14.4 & 9 & 9.6 & 6 & 24 & 15 \\
\hline Fuller et al. (2011) [11] ${ }^{1}$ & $\begin{array}{l}\text { Melbourne, } \\
\text { Australia }\end{array}$ & Outer suburb & Single-family & 2.5 & Source & 95.2 & 46.25 & 18.5 & 102.5 & 41 & 148.8 & 59.5 \\
\hline Stephan et al. (2013) $[10]^{2}$ & $\begin{array}{l}\text { Brussels, } \\
\text { Belgium }\end{array}$ & Outer suburb & Single-family & 4 & Source & 82.5 & 118.1 & 29.5 & 98 & 24.5 & 216.1 & 54 \\
\hline Du et al. (2015) [12] & $\begin{array}{c}\text { Chicago, } \\
\text { USA }\end{array}$ & Outer suburb & Single-family & 3.2 & Source & 66 & 242.9 & 75.9 & 64.6 & 20.2 & 307.5 & 96.1 \\
\hline This study & $\begin{array}{l}\text { Chicago, } \\
\text { USA }\end{array}$ & Inner suburb & Single-family & 3.3 & Source & 68.6 & 393.2 & 120.7 & 105.7 & 32.1 & 498.9 & 152.8 \\
\hline
\end{tabular}

Notes: ${ }^{1}$ Transportation in the studies by Fuller et al. [11] only considered the travel requirements for work; ${ }^{2}$ The TOE value listed in Stephan $e t$ al.'s study [10] in this table was the total transportation energy including both OE and EE. Due to limited information in Stephan et al.'s paper [10], the total transportation energy cannot be broken down into OE and EE specifically. 
BOE was estimated to be the single largest contributor of the total OE in both the downtown high-rise and suburban low-rise cases. BOE accounted for approximately $91 \%$ of the total OE in the downtown high-rise cases, and approximately $79 \%$ of the total $\mathrm{OE}$ in the suburban low-rise cases. Specifically, the average BOE in downtown high-rise cases was found to be $2.6 \mathrm{GJ} / \mathrm{m}^{2} /$ year, 388.4 GJ/HH/year, and 225.8 GJ/person/year. The average BOE in downtown high-rise cases was found to be $1.7 \mathrm{GJ} / \mathrm{m}^{2} /$ year, $393.2 \mathrm{GJ} / \mathrm{HH} /$ year, and $120.7 \mathrm{GJ} /$ person/year (see Tables 4 and 5). Interestingly, BOE, which has been widely confirmed as one of the largest contributors of the total $\mathrm{OE}$ associated with residential life, did not account for as large of a contribution in the studies by Norman et al., Perkins et al. and Stephan et al. $[3,7,10]$, largely due to higher BOE estimates in this study. For example, the ratio of annual BOE to total OE on a per-person basis was $78 \%$ in urban cases and 63\% in suburban cases in Norman et al. [3], 71\% in urban cases and 38\% in inner suburban cases in Perkins et al. and 63\% in urban cases and 55\% in inner suburban cases in Stephan et al. [10]. Specifically, Perkins et al. [7] used site energy instead of source energy, which could significantly lower their BOE value as well as the share of the total OE since electricity has a high primary energy conversion factor (typically $\sim 3$ ). Further, our estimates of BOE as a fraction of total OE are similar to those reported in Fuller et al. and Du et al. [11,12].

Reasons for these discrepancies likely include: (i) this study used empirical data that capture actual variations in human behaviors and lifestyles in buildings rather than modeled estimates of population averages; (ii) this study used data from existing buildings rather than new, energy-efficient buildings (which others have focused on); and (iii) BOE varies greatly with climate zone, envelope materials and thermal properties, vintage, equipment, occupancy, and many other parameters that may have differed in our sample of buildings. For example, Norman et al. and Fuller et al. [11] used country-wide average data for the specific cases in Toronto and Melbourne. Stephan et al. used relatively simple heat transfer models and regional averages for the determination of BOE. Du et al. [12] used modeled energy use of prototypical code-compliant residential buildings of recent construction in Chicago.

Discrepancies may also arise due to differences in the downtown housing cases chosen in this study. Specifically, the scale and function of the downtown housing cases in other studies were relatively small and simple, respectively. For example, the downtown housing case used in Norman et al. [3] was a single 15-story condo building in Toronto; Perkins et al. [7] used 6-8-story apartment buildings as downtown housing cases in Adelaide; Stephan et al. [10] used a 10-story apartment building in the city of Brussels; and Du et al. [12] used a prototypical code-compliant 10-story apartment building in Chicago. Thus, none of the prior cases are directly comparable to either the 27-story Commonwealth Plaza or the 73-story Legacy Building, both of which also have larger requirements for pumps, fans, lighting, etc., and also have a large number of common amenities. This study reveals a more realistic picture of operational energy consumption of tall residential buildings.

Based on the data collected on the residents' actual travel behaviors (in terms of travel distances and modes), TOE in this study was found to be greater than the values in all other previous urban high-density studies, and also greater than most other previous suburban low-rise studies. Specifically, automobile OE was found to be the single largest transport use, accounting for over $90 \%$ of transportation $\mathrm{OE}$ in both locations. The high parking space availability and car ownership in the four downtown residential towers in this study might have encouraged residents to own and drive automobiles (see Table 3). The average number of available parking spaces per unit in the downtown residential towers was 1.4, and the average car ownership per person in the downtown high-rise survey takers was 0.6, which was actually higher than the Oak Park low-rise survey takers. Differences may also be attributable in part to methodological differences between this study and others. For example, none of the other studies listed above conducted a detailed survey to investigate owned vehicle information (i.e., vehicle type, year, and distances traveled for various uses), or actual weekly travel behavior based on multiple major destinations (work, school, shopping, restaurant/entertainment, 
family/friends). The collected data on travel behavior, including frequency, travel time, and modes of travel (i.e., walking, bicycling, automobile, bus, local short-distance train, and long-distance commuter train) again allow for a more realistic assessment of TOE in these case study households.

\subsection{Research Limitations}

There are also a number of limitations to this study that should be noted. The four residential towers in this study, especially the Aqua Tower and the Legacy Building, are much taller than an average high-rise building. Specifically, both the Aqua Tower (262-m tall, 86-story) and the Legacy Building (250-m tall, 73-story) can nearly be categorized as "super-tall" buildings, which would likely consume more operational energy for elevators, water system, pumps, and fans than typical medium- or high-rise buildings. Moreover, both the Aqua Tower and the Legacy Building are luxury residential buildings that offer numerous high-quality on-site management service and amenities, which most certainly require more operational energy than the average residential tower. Additionally, these towers may be unique in that they resulted in a larger GFA/person than the low-rise cases (e.g., $77 \mathrm{~m}^{2}$ per person for Chicago high-rise cases compared to $69 \mathrm{~m}^{2}$ per person for Oak Park low-rise cases), which further resulted in greater operational energy consumption on a per-person basis in this study. For these combined reasons, the urban high-rise cases may not realistically represent typical high-rise residential buildings in downtown Chicago, although there are certainly many others similar to them.

For these reasons and others, this research could be extended in several ways. First, the embodied energy of these case study buildings and transportation infrastructure (i.e., roads, parking, bus/train stations, train tracks, etc.) was not quantified, which limited the analysis to operational energy rather than total life-cycle energy use. Some studies show that EE could be as important as OE from a life-cycle perspective $[10,11,45]$. Future work should also investigate these same measures across more building types, spanning from low-rise residential to super-tall high-rise structures, and across more residential locations. Moreover, energy consumption that is influenced by direct and indirect impacts resulting from interactions between individual buildings and surrounding urban settings could be considered and analyzed in future work [46]. Further, future research should also quantify the energy implications of more components of urban and suburban infrastructure, such as water, sewage, communications, and power supply and distribution. Lastly, other life-cycle environmental impact categories such as greenhouse gas (GHG) emissions and global warming potential (GWP) could also be quantified and compared between the urban high-rise and suburban low-rise lifestyles.

\section{Conclusions}

Overall, the empirical evidence in this paper provides a reasonably complete understanding of the operational energy use for buildings, transportation, and transportation infrastructure for both downtown high-rise and suburban low-rise living based on actual case studies in and around Chicago, IL. Data collected from over 500 households suggests that downtown high-rise living in this sample of urban residences in Chicago, IL accounts for approximately 427 GJ of source energy per household per year, on average, which was $14 \%$ lower than the average for suburban low-rise living in the Oak Park, IL homes. However, on a per-person basis, downtown high-rise living accounted for approximately 246 GJ per person per year, which was approximately $61 \%$ higher than suburban low-rise living. Results from this work can be used to better inform city planning on ways to prioritize energy-saving strategies in residential construction.

Acknowledgments: The authors gratefully acknowledge financial and technical support from the Council on Tall Buildings and Urban Habitat (CTBUH). The authors also recognize the following companies and organizations, which have supported this research: The Village of Oak Park, Oak Park Elementary School District 97, Mesa Development LLC, DK Condo for the Legacy at Millennium Park, Property Owner's Association of the Legacy at Millennium Park, Commonwealth Plaza Condominium Association, Green Initiative Committee of Commonwealth Plaza Condominium, Aqua at Lakeshore East Condominium, Aqua Condominium Association, 
Magellan Development Group, Solomon Cordwell Buenz (SCB) Architecture, Studio Gang Architects, and Walsh Construction.

Author Contributions: As the primary author, Peng Du initiated the study, performed the majority of the analysis, and wrote the main body of this paper. Antony Wood supervised the study, provided advice on the research scope, methodology, and data analysis, and also contributed in editing the paper. Brent Stephens contributed in structuring and editing the paper, advising on data analysis, and proofreading the manuscript.

Conflicts of Interest: The authors declare no conflict of interest.

\section{Abbreviations}

The following abbreviations are used in this manuscript:

$\begin{array}{ll}\text { BOE }_{\text {BOE }_{\mathrm{b}}} & \text { building operational energy } \\ \text { BOE }_{\mathrm{c}} & \text { building operational energy paid by the building management } \\ \text { BOE }_{\mathrm{e}} & \text { building operational energy via chilled water } \\ \text { BOE }_{\mathrm{g}} & \text { building operational energy via electric } \\ \text { BOE }_{\mathrm{i}} & \text { building operational energy via gas } \\ \text { CDD } & \text { building operational energy paid by the individual units } \\ \text { CMAP } & \text { cooling degree days } \\ \text { COP } & \text { Chicago Metropolitan Agency for Planning } \\ \text { CTA } & \text { coefficient of performance } \\ \text { D } & \text { Chicago Transit Authority } \\ \text { DOE } & \text { duplex } \\ \text { EE } & \text { Department of Energy } \\ \text { GFA } & \text { embodied energy } \\ \text { GHG } & \text { gross floor area } \\ \text { GJ } & \text { greenhouse gas } \\ \text { HDD } & \text { gigajoule } \\ \text { HH } & \text { heating degree days } \\ \text { LR } & \text { household } \\ \text { LCA } & \text { low-rise } \\ \text { MJ } & \text { life-cycle assessment } \\ \text { MPG } & \text { megajoule } \\ \text { OE } & \text { miles per gallon } \\ \text { PMT } & \text { operational energy } \\ \text { SD } & \text { passenger miles traveled } \\ \text { SF } & \text { standard deviation } \\ \text { TH } & \text { single family } \\ \text { TOE } & \text { townhouse } \\ \text { VMT } & \text { transportation operational energy } \\ \text { \# of Pred. Mo. } & \text { vehicle miles traveled } \\ & \text { the number of months predicted } \\ & \end{array}$


Appendix A. Vehicle Type Investigation of the Chicago Downtown and Oak Park Households

\begin{tabular}{|c|c|c|c|c|c|c|c|c|c|c|}
\hline \multirow{3}{*}{ Vehicle Type } & \multirow{2}{*}{\multicolumn{2}{|c|}{ Aqua }} & \multirow{2}{*}{\multicolumn{2}{|c|}{ Commonwealth }} & \multirow{2}{*}{\multicolumn{2}{|c|}{ Legacy }} & \multirow{2}{*}{\multicolumn{2}{|c|}{$\begin{array}{c}\text { Downtown High-Rise } \\
4 \text { Towers (Avg.) } \\
\end{array}$}} & \multirow{2}{*}{\multicolumn{2}{|c|}{$\begin{array}{c}\text { Suburban Low-Rise } \\
\text { Oak Park }\end{array}$}} \\
\hline & & & & & & & & & & \\
\hline & $\mathrm{CT}$ & $\%$ & $\mathrm{CT}$ & $\%$ & CT & $\%$ & CT & $\%$ & CT & $\%$ \\
\hline Sedan & 23 & $29.5 \%$ & 22 & $46.8 \%$ & 25 & $29.1 \%$ & 70 & $33.2 \%$ & 84 & $25.0 \%$ \\
\hline SUV & 25 & $32.1 \%$ & 8 & $17.1 \%$ & 28 & $32.6 \%$ & 61 & $28.9 \%$ & 79 & $23.5 \%$ \\
\hline Van/minivan & 2 & $2.6 \%$ & 0 & $0.0 \%$ & 5 & $5.8 \%$ & 7 & $3.3 \%$ & 43 & $12.8 \%$ \\
\hline Hatchback & 7 & $1.3 \%$ & 4 & $8.5 \%$ & 3 & $3.5 \%$ & 8 & $3.8 \%$ & 22 & $6.5 \%$ \\
\hline Wagon & 0 & $0.0 \%$ & 1 & $2.1 \%$ & 3 & $3.5 \%$ & 4 & $1.9 \%$ & 20 & $5.9 \%$ \\
\hline Pickup truck & 0 & $0.0 \%$ & 0 & $0.0 \%$ & 0 & $0.0 \%$ & 0 & $0.0 \%$ & 17 & $5.0 \%$ \\
\hline Crossover & 0 & $0.0 \%$ & 1 & $2.1 \%$ & 4 & $4.7 \%$ & 5 & $2.4 \%$ & 16 & $4.8 \%$ \\
\hline Convertible & 8 & $10.3 \%$ & 3 & $6.4 \%$ & 3 & $3.5 \%$ & 14 & $6.6 \%$ & 15 & $4.5 \%$ \\
\hline Hybrid & 4 & $5.1 \%$ & 7 & $14.9 \%$ & 5 & $5.8 \%$ & 16 & $7.6 \%$ & 13 & $3.9 \%$ \\
\hline Coupe & 7 & $9.0 \%$ & 0 & $0.0 \%$ & 1 & $1.2 \%$ & 8 & $3.8 \%$ & 12 & $3.6 \%$ \\
\hline Luxury & 4 & $5.1 \%$ & 0 & $0.0 \%$ & 8 & $9.3 \%$ & 12 & $5.7 \%$ & 5 & $1.5 \%$ \\
\hline Electric & 1 & $1.3 \%$ & 1 & $2.1 \%$ & 1 & $1.2 \%$ & 3 & $1.4 \%$ & 2 & $0.6 \%$ \\
\hline Motorcycle & 2 & $2.6 \%$ & 0 & $0.0 \%$ & 0 & $0.0 \%$ & 2 & $0.9 \%$ & 2 & $0.6 \%$ \\
\hline Other & 1 & $1.3 \%$ & 0 & $0.0 \%$ & 0 & $0.0 \%$ & 1 & $0.5 \%$ & 6 & $1.8 \%$ \\
\hline Total & 78 & $100 \%$ & 47 & $100 \%$ & 86 & $100 \%$ & 221 & $100 \%$ & 336 & $100 \%$ \\
\hline
\end{tabular}

Appendix B. Estimated Annual Operational Energy Consumption of the Oak Park Low-Rise Residential Buildings $(N=64)$

\begin{tabular}{|c|c|c|c|c|c|c|c|c|c|c|c|c|}
\hline H\# & $\begin{array}{l}\text { Bldg } \\
\text { Type }\end{array}$ & $\begin{array}{l}\text { GFA } \\
\left(m^{2}\right)\end{array}$ & $\begin{array}{l}\text { HH } \\
\text { Size }\end{array}$ & $\begin{array}{c}\mathrm{BOE}_{\mathrm{e}} \\
\left(\mathrm{MJ} / \mathrm{m}^{2} / \text { year }\right)\end{array}$ & $\begin{array}{c}\text { \# of Pred. } \\
\text { Mo. }\left(\mathrm{BOE}_{\mathrm{e}}\right)\end{array}$ & $\begin{array}{c}R^{2} \\
\left(\mathrm{BOE}_{\mathrm{e}}\right)\end{array}$ & $\begin{array}{c}\mathrm{BOE}_{\mathrm{g}} \\
\left(\mathrm{MJ} / \mathrm{m}^{2} / \text { year }\right)\end{array}$ & $\begin{array}{l}\text { \# of Pred. Mo. } \\
\quad\left(\mathrm{BOE}_{\mathrm{e}}\right)\end{array}$ & $\begin{array}{c}R^{2} \\
\left(\mathrm{BOE}_{\mathrm{g}}\right)\end{array}$ & $\begin{array}{c}\text { Total BOE } \\
\left(\mathrm{MJ} / \mathrm{m}^{2} / \text { year }\right)\end{array}$ & $\begin{array}{c}\text { Total BOE } \\
\text { (GJ/HH/year) }\end{array}$ & $\begin{array}{c}\text { Total BOE } \\
\text { (GJ/person/year) }\end{array}$ \\
\hline 1 & SF & 164.4 & 3 & 239.8 & 2 & 0.259 & 929.1 & 2 & 0.985 & 1168.9 & 192.2 & 64.1 \\
\hline 2 & SF & 111.5 & 3 & 874.4 & 1 & 0.528 & 1818.3 & 0 & $\mathrm{~N} / \mathrm{A}$ & 2692.7 & 300.2 & 100.1 \\
\hline 3 & SF & 92.9 & 3 & 322.6 & 2 & 0.029 & 699.7 & 2 & 0.967 & 1022.2 & 95.0 & 31.7 \\
\hline 4 & SF & 139.4 & 3 & 929.7 & 2 & 0.284 & 938 & 2 & 0.995 & 1867.7 & 260.3 & 86.8 \\
\hline 5 & $\mathrm{D}$ & 457 & 1 & 88.8 & 1 & 0.05 & 1180.1 & 3 & 0.979 & 1268.9 & 579.9 & 579.9 \\
\hline 6 & SF & 130.1 & 3 & 310 & 0 & N/A & 1319.6 & 1 & 0.931 & 1629.6 & 211.9 & 70.6 \\
\hline 7 & SF & 148.6 & 4 & 1137 & 1 & 0.001 & 2186.4 & 5 & 0.944 & 3323.4 & 494.0 & 123.5 \\
\hline 8 & SF & 111.5 & 1 & 461.1 & 0 & $\mathrm{~N} / \mathrm{A}$ & 445.8 & 2 & 0.489 & 906.9 & 101.1 & 101.1 \\
\hline 10 & $\mathrm{SF}$ & 418.1 & 5 & 487.1 & 2 & 0.108 & 1171.4 & 2 & 0.7 & 1658.5 & 693.3 & 138.7 \\
\hline
\end{tabular}




\begin{tabular}{|c|c|c|c|c|c|c|c|c|c|c|c|c|}
\hline H\# & $\begin{array}{l}\text { Bldg } \\
\text { Type }\end{array}$ & $\begin{array}{l}\text { GFA } \\
\left(\mathrm{m}^{2}\right)\end{array}$ & $\begin{array}{l}\text { HH } \\
\text { Size }\end{array}$ & $\begin{array}{c}\mathrm{BOE}_{\mathrm{e}} \\
\left(\mathrm{MJ} / \mathrm{m}^{2} / \text { year }\right)\end{array}$ & $\begin{array}{c}\text { \# of Pred. } \\
\text { Mo. }\left(\mathrm{BOE}_{\mathrm{e}}\right)\end{array}$ & $\begin{array}{c}R^{2} \\
\left(\mathrm{BOE}_{\mathrm{e}}\right)\end{array}$ & $\begin{array}{c}\mathrm{BOE}_{\mathrm{g}} \\
\left(\mathrm{MJ} / \mathrm{m}^{2} / \text { year }\right)\end{array}$ & $\begin{array}{l}\text { \# of Pred. Mo. } \\
\quad\left(\mathrm{BOE}_{\mathrm{e}}\right)\end{array}$ & $\begin{array}{c}R^{2} \\
\left(\mathrm{BOE}_{\mathrm{g}}\right)\end{array}$ & $\begin{array}{c}\text { Total BOE } \\
\left(\mathrm{MJ} / \mathrm{m}^{2} / \text { year) }\right.\end{array}$ & $\begin{array}{c}\text { Total BOE } \\
\text { (GJ/HH/year) }\end{array}$ & $\begin{array}{c}\text { Total BOE } \\
\text { (GJ/person/year) }\end{array}$ \\
\hline 11 & SF & 418.1 & 5 & 618.6 & 1 & 0.573 & 708.6 & 3 & 0.963 & 1327.2 & 554.8 & 111 \\
\hline 12 & SF & 334.4 & 4 & 416.5 & 2 & 0.533 & 924.3 & 2 & 0.756 & 1340.8 & 448.4 & 112.1 \\
\hline 13 & SF & 223 & 6 & 799.7 & 1 & 0.08 & 1255.5 & 1 & 0.729 & 2055.3 & 458.2 & 76.4 \\
\hline 14 & SF & 223 & 4 & 532.5 & 1 & 0.117 & 1206.7 & 1 & 0.958 & 1739.2 & 387.8 & 96.9 \\
\hline 15 & $\mathrm{TH}$ & 172.8 & 3 & 470.8 & 1 & 0.251 & 477.4 & 2 & 0.958 & 948.2 & 163.8 & 54.6 \\
\hline 16 & $\mathrm{TH}$ & 195.1 & 5 & 1505.5 & 1 & 0.72 & 0 & 0 & N/A & 1505.5 & 293.7 & 58.7 \\
\hline 17 & SF & 325.2 & 3 & 360.8 & 2 & 0.082 & 796.7 & 2 & 0.768 & 1157.5 & 376.4 & 125.5 \\
\hline 18 & $\mathrm{TH}$ & 232.3 & 1 & 188 & 2 & 0.038 & 951.3 & 1 & 0.698 & 1139.3 & 264.6 & 264.6 \\
\hline 20 & SF & 234.9 & 3 & 506.1 & 1 & 0.057 & 1234.1 & 2 & 0.898 & 1740.2 & 408.7 & 136.2 \\
\hline 21 & LR & 116.1 & 2 & 657.4 & 1 & 0.611 & 996.2 & 1 & 0.968 & 1653.6 & 192.0 & 96 \\
\hline 22 & SF & 148.6 & 3 & 478.1 & 1 & 0.005 & 1309 & 1 & 0.98 & 1787.2 & 265.6 & 88.5 \\
\hline 23 & SF & 557.4 & 5 & 624 & 1 & 0.231 & 918.1 & 2 & 0.712 & 1542.1 & 859.5 & 171.9 \\
\hline 24 & SF & 260.1 & 5 & 1316.4 & 0 & $\mathrm{~N} / \mathrm{A}$ & 1272.9 & 1 & 0.969 & 2589.2 & 673.5 & 134.7 \\
\hline 25 & SF & 176.5 & 3 & 958.6 & 1 & 0.191 & 1944.5 & 2 & 0.985 & 2903.2 & 512.4 & 170.8 \\
\hline 26 & $\mathrm{TH}$ & 185.8 & 2 & 761.3 & 1 & 0.128 & 942.6 & 2 & 0.799 & 1703.8 & 316.6 & 158.3 \\
\hline 27 & SF & 353 & 6 & 680.3 & 1 & 0.018 & 1320.2 & 1 & 0.75 & 2000.6 & 706.2 & 117.7 \\
\hline 28 & SF & 130.1 & 4 & 875.4 & 1 & 0.03 & 1130.2 & 2 & 0.908 & 2005.7 & 260.9 & 65.2 \\
\hline 29 & SF & 325.2 & 5 & 471.3 & 0 & N/A & 750 & 1 & 0.978 & 1221.3 & 397.1 & 79.4 \\
\hline 32 & $\mathrm{TH}$ & 223 & 3 & 307.4 & 1 & 0.415 & 546.7 & 1 & 0.962 & 854.1 & 190.4 & 63.5 \\
\hline 33 & SF & 232.3 & 5 & 703.5 & 0 & N/A & 1010 & 2 & 0.965 & 1713.6 & 398.0 & 79.6 \\
\hline 34 & SF & 278.7 & 4 & 614.8 & 1 & 0.004 & 1415.8 & 1 & 0.966 & 2030.6 & 565.9 & 141.5 \\
\hline 35 & SF & 390.2 & 4 & 444 & 1 & 0.065 & 726.7 & 1 & 0.796 & 1170.6 & 456.8 & 114.2 \\
\hline 36 & LR & 88.3 & 2 & 626 & 0 & N/A & 0 & 0 & N/A & 626 & 55.2 & 27.6 \\
\hline 37 & SF & 260.1 & 4 & 654.7 & 1 & 0.226 & 917.2 & 1 & 0.74 & 1571.9 & 408.9 & 102.2 \\
\hline 38 & SF & 157.9 & 2 & 636 & 0 & N/A & 849.8 & 0 & N/A & 1485.8 & 234.7 & 117.3 \\
\hline 39 & SF & 167.2 & 2 & 1553.6 & 1 & 0.025 & 1517.4 & 1 & 0.98 & 3071 & 513.5 & 256.8 \\
\hline 40 & SF & 195.1 & 5 & 667.8 & 1 & 0.132 & 1017 & 3 & 0.618 & 1684.8 & 328.7 & 65.7 \\
\hline 41 & SF & 185.8 & 2 & 409.2 & 0 & N/A & 1274.4 & 1 & 0.989 & 1683.6 & 312.8 & 156.4 \\
\hline 42 & SF & 250.8 & 6 & 1567 & 0 & N/A & 941 & 2 & 0.976 & 2507.9 & 629.1 & 104.8 \\
\hline 43 & SF & 176.5 & 4 & 939.9 & 1 & 0.034 & 1232.6 & 1 & 0.968 & 2172.5 & 383.5 & 95.9 \\
\hline 44 & SF & 278.7 & 5 & 908.9 & 0 & $\mathrm{~N} / \mathrm{A}$ & 1005.1 & 2 & 0.986 & 1914 & 533.4 & 106.7 \\
\hline 45 & SF & 157.3 & 4 & 305.5 & 3 & 0.528 & 947.8 & 3 & 0.874 & 1253.3 & 197.1 & 49.3 \\
\hline 46 & SF & 171.9 & 4 & 430.8 & 0 & N/A & 1061.8 & 0 & N/A & 1492.6 & 256.5 & 64.1 \\
\hline 47 & SF & 167.2 & 6 & 973.3 & 1 & 0.123 & 825.3 & 1 & 0.93 & 1798.6 & 300.8 & 50.1 \\
\hline 48 & SF & 241.5 & 4 & 659.7 & 0 & $\mathrm{~N} / \mathrm{A}$ & 1532.9 & 1 & 0.968 & 2192.6 & 529.6 & 132.4 \\
\hline 49 & SF & 371.6 & 2 & 407.3 & 0 & $\mathrm{~N} / \mathrm{A}$ & 1104.6 & 1 & 0.948 & 1511.9 & 561.8 & 280.9 \\
\hline 50 & SF & 275.6 & 2 & 76.9 & 0 & N/A & 809.8 & 1 & 0.688 & 886.7 & 244.4 & 122.2 \\
\hline
\end{tabular}




\begin{tabular}{|c|c|c|c|c|c|c|c|c|c|c|c|c|}
\hline H\# & $\begin{array}{l}\text { Bldg } \\
\text { Type }\end{array}$ & $\begin{array}{l}\text { GFA } \\
\left(\mathrm{m}^{2}\right)\end{array}$ & $\begin{array}{l}\text { HH } \\
\text { Size }\end{array}$ & $\begin{array}{c}\mathrm{BOE}_{\mathrm{e}} \\
\left(\mathrm{MJ} / \mathrm{m}^{2} / \text { year }\right)\end{array}$ & $\begin{array}{c}\text { \# of Pred. } \\
\text { Mo. }\left(\mathrm{BOE}_{\mathrm{e}}\right)\end{array}$ & $\begin{array}{c}R^{2} \\
\left(\mathrm{BOE}_{\mathrm{e}}\right)\end{array}$ & $\begin{array}{c}\mathrm{BOE}_{\mathrm{g}} \\
\left(\mathrm{MJ} / \mathrm{m}^{2} / \text { year }\right)\end{array}$ & $\begin{array}{l}\text { \# of Pred. Mo. } \\
\quad\left(\mathrm{BOE}_{\mathrm{e}}\right)\end{array}$ & $\begin{array}{c}R^{2} \\
\left(\mathrm{BOE}_{\mathrm{g}}\right)\end{array}$ & $\begin{array}{c}\text { Total BOE } \\
\left(\mathrm{MJ} / \mathrm{m}^{2} / \text { year }\right)\end{array}$ & $\begin{array}{c}\text { Total BOE } \\
\text { (GJ/HH/year) }\end{array}$ & $\begin{array}{c}\text { Total BOE } \\
\text { (GJ/person/year) }\end{array}$ \\
\hline 51 & $\mathrm{SF}$ & 82.7 & 3 & 653.9 & 1 & 0.211 & 1810.5 & 1 & 0.81 & 2464.4 & 203.8 & 67.9 \\
\hline 52 & SF & 260.1 & 4 & 418 & 0 & N/A & 1105.6 & 0 & N/A & 1523.6 & 396.3 & 99.1 \\
\hline 53 & $\mathrm{SF}$ & 334.4 & 4 & 381.1 & 1 & 0.011 & 1320.7 & 0 & N/A & 1701.8 & 569.1 & 142.3 \\
\hline 54 & SF & 255.5 & 4 & 352.7 & 0 & N/A & 828 & 1 & 0.926 & 1180.7 & 301.7 & 75.4 \\
\hline 55 & $\mathrm{TH}$ & 102.2 & 4 & 500.7 & 4 & 0.842 & 891.1 & 4 & 0.359 & 1391.7 & 142.2 & 35.6 \\
\hline 56 & SF & 152.4 & 2 & 578.3 & 1 & 0.162 & 1377.1 & 3 & 0.991 & 1955.4 & 297.9 & 149 \\
\hline 57 & SF & 511 & 4 & 535.4 & 4 & 0.346 & 1028.5 & 4 & 0.824 & 1564 & 799.1 & 199.8 \\
\hline 58 & SF & 241.5 & 5 & 721.4 & 1 & 0.277 & 1076.2 & 2 & 0.842 & 1797.5 & 434.2 & 86.8 \\
\hline 60 & SF & 311.8 & 4 & 354.1 & 3 & 0.166 & 938.4 & 4 & 0.728 & 1292.4 & 402.9 & 100.7 \\
\hline 61 & SF & 195.1 & 3 & 402.7 & 1 & 0.003 & 986.5 & 0 & N/A & 1389.3 & 271.0 & 90.3 \\
\hline 62 & SF & 148.6 & 2 & 591.3 & 0 & N/A & 1354.8 & 0 & N/A & 1946.1 & 289.3 & 144.6 \\
\hline 63 & SF & 92.9 & 2 & 1406.9 & 0 & N/A & 1213.1 & 1 & 0.697 & 2620 & 243.4 & 121.7 \\
\hline 64 & SF & 125.8 & 4 & 513.1 & 2 & 0.289 & 813.5 & 1 & 0.917 & 1326.6 & 166.9 & 41.7 \\
\hline
\end{tabular}

Appendix C. Estimated Annual Operational Energy Consumption Paid by the bUilding Management for the Chicago Downtown Residential Towers

\begin{tabular}{|c|c|c|}
\hline Measure & Commonwealth & Legacy \\
\hline $\operatorname{GFA}\left(\mathrm{m}^{2}\right)$ & 54396 & 70153 \\
\hline Site $\mathrm{BOE}_{\mathrm{e}}\left(\mathrm{MJ} / \mathrm{m}^{2} /\right.$ year $)$ & 149.9 & 585.5 \\
\hline Source $\mathrm{BOE}_{\mathrm{e}}\left(\mathrm{MJ} / \mathrm{m}^{2} /\right.$ year $)$ & 474.6 & 1854.2 \\
\hline \# of Pred. Mo. $\left(\mathrm{BOE}_{\mathrm{e}}\right)$ & 1 & 0 \\
\hline$R^{2}\left(\mathrm{BOE}_{\mathrm{e}}\right)$ & 0.440 & $\mathrm{~N} / \mathrm{A}$ \\
\hline Site $\mathrm{BOE}_{\mathrm{g}}\left(\mathrm{MJ} / \mathrm{m}^{2} /\right.$ year $)$ & 1009.8 & 114.6 \\
\hline Source $\mathrm{BOE}_{\mathrm{g}}\left(\mathrm{MJ} / \mathrm{m}^{2} /\right.$ year $)$ & 1094.6 & 124.2 \\
\hline \# of Pred. Mo. $\left(\mathrm{BOE}_{\mathrm{g}}\right)$ & 1 & 1 \\
\hline$R^{2}\left(\mathrm{BOE}_{\mathrm{g}}\right)$ & 0.986 & 0.950 \\
\hline Site $\mathrm{BOE}_{\mathrm{c}}\left(\mathrm{MJ} / \mathrm{m}^{2} /\right.$ year $)$ & 0 & 243.1 \\
\hline Source $\mathrm{BOE}_{\mathrm{c}}\left(\mathrm{MJ} / \mathrm{m}^{2} /\right.$ year $)$ & 0 & 126.2 \\
\hline \# of Pred. Mo. $\left(\mathrm{BOE}_{\mathrm{c}}\right)$ & 0 & 0 \\
\hline$R^{2}\left(\mathrm{BOE}_{\mathrm{c}}\right)$ & $\mathrm{N} / \mathrm{A}$ & $\mathrm{N} / \mathrm{A}$ \\
\hline Total Site $\mathrm{BOE}_{\mathrm{b}}\left(\mathrm{MJ} / \mathrm{m}^{2} /\right.$ year $)$ & 1159.7 & 943.2 \\
\hline Total Source $\mathrm{BOE}_{\mathrm{b}}\left(\mathrm{MJ} / \mathrm{m}^{2} /\right.$ year $)$ & 1569.2 & 2104.6 \\
\hline
\end{tabular}


Appendix D. Estimated Annual Total Operational Energy Consumption in the Chicago Downtown Residential Towers $(N=42)$

\begin{tabular}{|c|c|c|c|c|c|c|c|c|c|c|c|c|}
\hline $\mathbf{H} \#$ & $\begin{array}{l}\text { GFA } \\
\left(\mathrm{m}^{2}\right)\end{array}$ & $\begin{array}{l}\text { HH } \\
\text { Size }\end{array}$ & $\begin{array}{l}\text { Site } \mathrm{BOE}_{\mathrm{i}} \\
\left(\mathrm{MJ} / \mathrm{m}^{2} / \text { year }\right)\end{array}$ & $\begin{array}{l}\text { Source BOE } \\
\left(\mathrm{MJ} / \mathrm{m}^{2} / \text { year }\right.\end{array}$ & $\begin{array}{c}\text { \# of Pred. } \\
\text { Mo. } \\
\left(\mathrm{BOE}_{\mathrm{i}}\right)\end{array}$ & $\begin{array}{c}R^{2} \\
\left(\mathrm{BOE}_{\mathrm{i}}\right)\end{array}$ & $\begin{array}{l}\text { Total Site } \\
\text { BOE } \\
\text { (MJ/m²/year) }\end{array}$ & $\begin{array}{c}\text { Total Source } \\
\text { BOE } \\
\text { (MJ/m²/year) }\end{array}$ & $\begin{array}{l}\text { Total Site } \\
\text { BOE } \\
\text { (GJ/HH/year) }\end{array}$ & $\begin{array}{c}\text { Total Source } \\
\text { BOE } \\
\text { (GJ/HH/year) }\end{array}$ & $\begin{array}{l}\text { Total Site BOE } \\
\text { (GJ/person/year) }\end{array}$ & $\begin{array}{c}\text { Total Source } \\
\text { BOE } \\
\text { (GJ/person/year) }\end{array}$ \\
\hline $\mathrm{C} 1$ & 111.48 & 1 & 148.1 & 469.2 & 1 & 0.280 & 1307.8 & 2038.4 & 145.8 & 227.2 & 145.8 & 227.2 \\
\hline $\mathrm{C} 2$ & 157.93 & 4 & 87.6 & 277.5 & 1 & 0.630 & 1247.3 & 1846.7 & 197.0 & 291.7 & 49.2 & 72.9 \\
\hline C3 & 102.19 & 2 & 280.5 & 888.3 & 0 & $\mathrm{~N} / \mathrm{A}$ & 1440.2 & 2457.6 & 147.2 & 251.1 & 73.6 & 125.6 \\
\hline C4 & 134.705 & 2 & 106.9 & 338.4 & 1 & 0.328 & 1266.5 & 1907.6 & 170.6 & 257.0 & 85.3 & 128.5 \\
\hline C5 & 104.6983 & 2 & 163.0 & 516.2 & 0 & N/A & 1322.6 & 2085.4 & 138.5 & 218.3 & 69.2 & 109.2 \\
\hline C6 & 111.48 & 1 & 80.1 & 253.7 & 4 & 0.476 & 1239.8 & 1822.9 & 138.2 & 203.2 & 138.2 & 203.2 \\
\hline C7 & 69.675 & 1 & 122.2 & 387.1 & 1 & 0.189 & 1281.9 & 1956.3 & 89.3 & 136.3 & 89.3 & 136.3 \\
\hline $\mathrm{C} 8$ & 78.965 & 1 & 89.7 & 284.0 & 1 & 0.060 & 1249.3 & 1853.2 & 98.7 & 146.3 & 98.7 & 146.3 \\
\hline C9 & 107.4853 & 2 & 81.9 & 259.4 & 4 & 0.342 & 1241.6 & 1828.6 & 133.5 & 196.6 & 66.7 & 98.3 \\
\hline $\mathrm{C} 10$ & 106.835 & 1 & 98.1 & 310.8 & 2 & 0.189 & 1257.8 & 1880.0 & 134.4 & 200.8 & 134.4 & 200.8 \\
\hline $\mathrm{C} 11$ & 92.9 & 3 & 59.1 & 187.3 & 4 & 0.404 & 1218.8 & 1756.5 & 113.2 & 163.2 & 37.7 & 54.4 \\
\hline C12 & 102.19 & 2 & 145.4 & 460.4 & 2 & 0.393 & 1305.0 & 2029.6 & 133.4 & 207.4 & 66.7 & 103.7 \\
\hline $\mathrm{C} 13$ & 260.12 & 4 & 210.5 & 666.5 & 0 & N/A & 1370.1 & 2235.8 & 356.4 & 581.6 & 89.1 & 145.4 \\
\hline C14 & 167.22 & 1 & 107.2 & 339.6 & 2 & 0.378 & 1266.9 & 1908.9 & 211.9 & 319.2 & 211.9 & 319.2 \\
\hline $\mathrm{C} 15$ & 65.03 & 1 & 140.4 & 444.6 & 2 & 0.009 & 1300.0 & 2013.8 & 84.5 & 131.0 & 84.5 & 131.0 \\
\hline $\mathrm{C} 16$ & 111.48 & 1 & 117.6 & 372.4 & 3 & 0.013 & 1277.2 & 1941.6 & 142.4 & 216.5 & 142.4 & 216.5 \\
\hline $\mathrm{C} 17$ & 111.48 & 5 & 127.6 & 404.0 & 1 & 0.096 & 1287.2 & 1973.2 & 143.5 & 220.0 & 28.7 & 44.0 \\
\hline $\mathrm{C} 18$ & 46.45 & 2 & 274.6 & 869.6 & 3 & 0.027 & 1434.3 & 2438.9 & 66.6 & 113.3 & 33.3 & 56.6 \\
\hline C19 & 260.12 & 2 & 78.7 & 249.2 & 3 & 0.164 & 1238.3 & 1818.4 & 322.1 & 473.0 & 161.1 & 236.5 \\
\hline C20 & 116.125 & 1 & 86.1 & 272.8 & 0 & N/A & 1245.8 & 1842.0 & 144.7 & 213.9 & 144.7 & 213.9 \\
\hline L21 & 185.8 & 2 & 157.1 & 497.5 & 0 & $\mathrm{~N} / \mathrm{A}$ & 1100.3 & 2602.2 & 204.4 & 483.5 & 102.2 & 241.7 \\
\hline L22 & 90.6 & 2 & 226.9 & 718.7 & 4 & 0.936 & 1170.1 & 2823.3 & 106.0 & 255.7 & 53.0 & 127.9 \\
\hline L23 & 185.4 & 2 & 499.0 & 1580.4 & 0 & $\mathrm{~N} / \mathrm{A}$ & 1442.2 & 3685.0 & 267.4 & 683.3 & 133.7 & 341.7 \\
\hline L24 & 139.4 & 2 & 224.5 & 711.1 & 0 & N/A & 1167.7 & 2815.8 & 162.7 & 392.4 & 81.4 & 196.2 \\
\hline L25 & 102.2 & 2 & 382.5 & 1211.3 & 0 & N/A & 1325.7 & 3315.9 & 135.5 & 338.9 & 67.7 & 169.4 \\
\hline L26 & 226.3 & 2 & 340.3 & 1077.8 & 0 & $\mathrm{~N} / \mathrm{A}$ & 1283.5 & 3182.5 & 290.5 & 720.2 & 145.2 & 360.1 \\
\hline L27 & 745.2 & 2 & 114.5 & 362.7 & 0 & $\mathrm{~N} / \mathrm{A}$ & 1057.7 & 2467.3 & 788.2 & 1838.7 & 394.1 & 919.4 \\
\hline L28 & 185.8 & 3 & 419.7 & 1329.3 & 5 & 0.870 & 1362.9 & 3433.9 & 253.2 & 638.0 & 84.4 & 212.7 \\
\hline L29 & 167.2 & 1 & 147.2 & 466.3 & 1 & 0.723 & 1090.4 & 2571.0 & 182.3 & 429.9 & 182.3 & 429.9 \\
\hline L30 & 139.4 & 2 & 107.5 & 340.4 & 1 & 0.555 & 1050.7 & 2445.0 & 146.4 & 340.7 & 73.2 & 170.4 \\
\hline L31 & 185.8 & 1 & 143.5 & 454.4 & 2 & 0.607 & 1086.7 & 2559.1 & 201.9 & 475.5 & 201.9 & 475.5 \\
\hline L32 & 131.9 & 2 & 634.1 & 2008.1 & 1 & 0.843 & 1577.3 & 4112.8 & 208.1 & 542.5 & 104.0 & 271.3 \\
\hline L33 & 274.1 & 2 & 198.7 & 629.2 & 1 & 0.377 & 1141.8 & 2733.8 & 312.9 & 749.2 & 156.5 & 374.6 \\
\hline L34 & 185.8 & 2 & 186.2 & 589.6 & 0 & N/A & 1129.4 & 2694.3 & 209.8 & 500.6 & 104.9 & 250.3 \\
\hline L35 & 139.4 & 2 & 274.5 & 869.3 & 0 & N/A & 1217.7 & 2973.9 & 169.7 & 414.4 & 84.8 & 207.2 \\
\hline L36 & 92.9 & 2 & 228.2 & 722.7 & 2 & 0.640 & 1171.4 & 2827.3 & 108.8 & 262.7 & 54.4 & 131.3 \\
\hline L37 & 115.4 & 1 & 270.9 & 858.0 & 5 & 0.838 & 1214.1 & 2962.6 & 140.1 & 341.8 & 140.1 & 341.8 \\
\hline L38 & 139.4 & 2 & 290.0 & 918.3 & 1 & 0.737 & 1233.1 & 3022.9 & 171.8 & 421.2 & 85.9 & 210.6 \\
\hline L39 & 139.4 & 2 & 428.3 & 1356.4 & 2 & 0.758 & 1371.5 & 3461.1 & 191.1 & 482.3 & 95.6 & 241.1 \\
\hline L40 & 110.2 & 2 & 286.3 & 906.6 & 0 & $\mathrm{~N} / \mathrm{A}$ & 1229.4 & 3011.2 & 135.5 & 331.8 & 67.7 & 165.9 \\
\hline L41 & 139.4 & 1 & 342.6 & 1085.1 & 2 & 0.879 & 1285.8 & 3189.8 & 179.2 & 444.5 & 179.2 & 444.5 \\
\hline L42 & 139.4 & 2 & 376.3 & 1191.8 & 2 & 0.907 & 1319.5 & 3296.4 & 183.9 & 459.4 & 91.9 & 229.7 \\
\hline
\end{tabular}




\section{References and Notes}

1. United Nations. World Population Prospects: The 2006 Revision; ST/ESA/SER.A/261/ES; United Nations: New York, NY, USA, 2007.

2. Newman, P.W.G.; Kenworthy, J.R. Gasoline consumption and cities. J. Am. Plan. Assoc. 1989, 55, $24-37$. [CrossRef]

3. Norman, J.; MacLean, H.L.; Kennedy, C.A. Comparing high and low residential density: Life-cycle analysis of energy use and greenhouse gas emissions. J. Urban Plan. Dev. 2006, 132, 10-21. [CrossRef]

4. Ewing, R.; Rong, F. The impact of urban form on U.S. residential energy use. House Policy Debate 2008, 19, 1-30. [CrossRef]

5. Nichols, B.G.; Kockelman, K. Urban form and life-cycle energy consumption: Case studies at the city scale. J. Transp. Land Use 2015, 8, 115-129. [CrossRef]

6. Erickson, P.; Tempest, K. Keeping Cities Green: Avoiding Carbon Lock-in Due to Urban Development; Stockholm Environment Institute: Seattle, WA, USA, 2015.

7. Perkins, A.; Hamnett, S.; Pullen, S.; Zito, R.; Trebilcock, D. Transport, housing and urban form: The life cycle energy consumption and emissions of city centre apartments compared with suburban dwellings. Urban Policy Res. 2009, 27, 377-396. [CrossRef]

8. Bastos, J.; Batterman, S.A.; Freire, F. Significance of mobility in the life-cycle assessment of buildings. Build. Res. Inf. 2016, 44, 376-393. [CrossRef]

9. Gudipudi, R.; Fluschnik, T.; Ros, A.G.C.; Walther, C.; Kropp, J.P. City density and $\mathrm{CO}_{2}$ efficiency. Energy Policy 2016, 91, 352-361. [CrossRef]

10. Stephan, A.; Crawford, R.H.; de Myttenaere, K. A comprehensive assessment of the life cycle energy demand of passive houses. Appl. Energy 2013, 112, 23-34. [CrossRef]

11. Fuller, R.J.; Crawford, R.H. Impact of past and future residential housing development patterns on energy demand and related emissions. J. House Built Environ. 2011, 26, 65-183. [CrossRef]

12. Du, P.; Wood, A.; Stephens, B.; Song, X. Life-cycle energy implications of downtown high-rise vs. suburban low-rise living: An overview and quantitative case study for Chicago. Buildings 2015, 5, 1003-1024. [CrossRef]

13. Heinonen, J.; Junnila, S. A carbon consumption comparison of rural and urban lifestyles. Sustainability 2011, 3, 1234-1249. [CrossRef]

14. Heinonen, J.; Junnila, S. Implications of urban structure on carbon consumption in metropolitan areas. Environ. Res. Lett. 2011, 6, 014018. [CrossRef]

15. Heinonen, J.; Kyrö, R.; Junnila, S. Dense downtown living more carbon intense due to higher consumption: a case study of Helsinki. Environ. Res. Lett. 2011, 6, 034034. [CrossRef]

16. Heinonen, J.; Jalas, M.; Juntunen, J.K.; Ala-Mantila, S.; Junnila, S. Situated lifestyles: II. The impacts of urban density, housing type and motorization on the greenhouse gas emissions of the middle-income consumers in Finland. Environ. Res. Lett. 2013, 8, 35050. [CrossRef]

17. Wilson, J.; Spinney, J.; Millward, H.; Scott, D.; Hayden, A.; Tyedmers, P. Blame the exurbs, not the suburbs: Exploring the distribution of greenhouse gas emissions within a city region. Energy Policy 2013, 62, 1329-1335. [CrossRef]

18. Optis, M.; Wild, P. Inadequate documentation in published life cycle energy reports on buildings. Int. J. Life Cycle Assess. 2010, 15, 644-651. [CrossRef]

19. CTBUH. The Skyscraper Center. Available online: http://www.skyscrapercenter.com/ (accessed on 28 March 2016).

20. US Census Bureau. Census.gov. Available online: http://www.census.gov / (accessed on 28 March 2016).

21. The chilled water in the Aqua Tower and Legacy Building is provided by the city's district chilled water system, Thermal Chicago, which serves over 100 buildings within the city. It is one of the most advanced, reliable, and efficient cooling systems in the world. The system includes five chilled water generation plants serving the Loop, West Loop, South Loop and River North areas [22,23]. Commonwealth Plaza has its own chillers, so does not have chilled water bills from Thermal Chicago.

22. Thermal Chicago Corporation. Available online: http://www.esdglobal.com/news/article/673-thermalchicago-corporation (accessed on 27 September 2015).

23. Climate Control Middle East. Chilled out in Chicago. 31 October 2011. Available online: http: / / climatecontrolme.com/2011/10/chilled-out-in-chicago/ (accessed on 28 March 2016). 
24. U.S. Energy Information Administration. Annual Energy Outlook 2014; DOE/EIA-0383(2014); U.S. Energy Information Administration: Washington, DC, USA, 2014.

25. Deru, M.; Torcellini, P. Source Energy and Emission Factors for Energy Use in Buildings; NREL/TP-550-38617; National Renewable Energy Laboratory: Golden, CO, USA, 2007.

26. American Society of Heating, Refrigerating and Air-Conditioning Engineers. 2013 ASHRAE Handbook: Fundamentals; American Society of Heating, Refrigeration and Air-Conditioning Engineers: Atlanta, GA, USA, 2013.

27. U.S. Department of Energy. 90.1 Prototype Building Models High-rise Apartment. Available online: https: //www.energycodes.gov/901-prototype-building-models-high-rise-apartment (accessed on 5 July 2015).

28. Stanford, H.W., III. HVAC Water Chillers and Cooling Towers: Fundamentals, Application, and Operation; CRC Press: Boca Raton, FL, USA, 2003.

29. American Society of Heating, Refrigerating and Air-Conditioning Engineers. ANSI/ASHRAE/IES Standard 90.1-2007-Energy Standard for Buildings Except Low-Rise Residential Buildings; American Society of Heating, Refrigeration and Air-Conditioning Engineers: Atlanta, GA, USA, 2007.

30. Fuel Economy. FuelEconomy.gov. Available online: http://www.fueleconomy.gov/ (accessed on 15 August 2015).

31. tLCAdb. Transportation LCA I Passenger Database. Available online: http://transportationlca.org/tlcadbpassenger.php (accessed on 9 August 2015).

32. Chester, M.V. Life-cycle Environmental Inventory of Passenger Transportation in the United States. Ph.D. Thesis, University of California, Berkeley, CA, USA, 2008.

33. Chester, M.V.; Horvath, A.; Madanat, S. Comparison of life-cycle energy and emissions footprints of passenger transportation in metropolitan regions. Atmos. Environ. 2010, 44, 1071-1079. [CrossRef]

34. Combined MPG for each specific automobile vehicle reported in the survey is used, which can be found from FuelEconomy.gov [30].

35. Vesilind, P.A.; Morgan, S.M.; Heine, L.G. Introduction to Environmental Engineering; Cengage Learning: Belmont, CA, USA, 2009.

36. Bunkley, N. Toyota Ends 2013 down while Lexus Rises, 3 January 2014. Automotive News. Available online: http:/ / www.autonews.com/article/20140103/RETAIL01/140109960/toyota-ends-2013-downwhile-lexus-rises (accessed on 17 August 2015).

37. Cain, T. Top 10 Best-Selling SUVs in America-2005 Year End, 30 April 2014. Good Car Bad Car. Available online: http:/ /www.goodcarbadcar.net/2014/04/usa-10-best-selling-suv-crossover-2005-year-end.html (accessed on 17 August 2015).

38. The Combined MPG of the 2008, 2006, and 2010 Toyota Camry is 25, 25, and 26, respectively, and the Combined MPG of the 2005 Chevrolet TrailBlazer is 16. Source: FuelEconomy.gov [30].

39. In order to quantify the energy use on a per passenger basis, the average occupancy of a CTA bus, CTA train, and Metra train in Chicago was assumed to be 12,92, and 245, respectively, by the tLCAdb researchers [32] (p. 293).

40. CMAP. Community Data Snapshots. Available online: http://www.cmap.illinois.gov/data/metropulse/ community-snapshots (accessed on 5 May 2016).

41. The individual homes across all the four downtown residential towers only received electric bills.

42. The Legacy is fully clad with a thermally efficient unitized curtain wall featuring "low-E" and Argon-filled insulating glass units. Also, connection to the city's district chilled water system is estimated to eliminate the need for three 600-ton water chillers and associated cooling towers on the building roof [43].

43. Noone, P.; Klompmaker, G.; Sumanik, C. The high life: residential towers in central business districts. СТВUН J. 2011, 36-41.

44. Walking, bicycle and "Other" mode of transport are excluded in the OE analysis.

45. Crawford, R. An as-occupied life cycle energy assessment of a residential building. In Proceedings of the 46th Annual Conference of the Architectural Science Association, Gold Coast, Australia, 14-16 November 2012.

46. Anderson, J.E.; Wulfhorst, G.; Lang, W. Expanding the use of life-cycle assessment to capture induced impacts in the built environment. Build. Environ. 2015, 94, 403-416. [CrossRef]

(C) 2016 by the authors; licensee MDPI, Basel, Switzerland. This article is an open access article distributed under the terms and conditions of the Creative Commons Attribution (CC-BY) license (http://creativecommons.org/licenses/by/4.0/). 